\title{
Corporate Governance Quality, Audit Fees and Non-Audit Services Fees
}

\author{
Mahbub Zaman, Mohammed Hudaib and Roszaini Haniffa*
}

\begin{abstract}
This paper extends prior research on the relationship between governance quality and auditor remuneration. We examine the influence of audit committee effectiveness (ACE), a proxy for governance quality, on audit fees (AF) and non-audit services fees (NASF) using a new composite measure comprising audit committee independence, expertise, diligence and size. We find that after controlling for board of director characteristics, there is a significant positive association between ACE and AF only for larger clients. Our results indicate that effective audit committees undertake more monitoring which results in wider audit scope and higher audit fees. Contrary to our expectations, we find the association between ACE and NASF to be positive and significant, especially for larger clients. This suggests that larger clients are more likely to purchase non-audit services (NAS) even in the presence of effective audit committees probably due to the complexity of their activities. Overall, our findings support regulatory initiatives aimed at improving corporate governance quality.
\end{abstract}

Keywords: audit committees, corporate governance, non-executive directors, audit fees, nonaudit services, audit quality

\section{INTRODUCTION}

Corporate governance reforms concerning the effectiveness of boards and audit committees are intended to improve financial reporting and audit quality (Beasley et al., 2009; Cohen et al., 2004; Conyon, 2000; Krishnan and Visvanathan, 2009; Larcker and Richardson, 2004; Peasnell et al., 2000; and Turley and Zaman, 2007). Effective boards and audit committees are expected to lead to higher transparency and reliability of financial statements as well as reduce the risk of the auditor providing an incorrect audit opinion (McElveen, 2002; Turley and Zaman, 2004; and Young, 2000). Moreover, they are expected to protect auditor independence by assuming responsibility for the appointment and remuneration of auditors, and providing an independent platform for auditors to express their opinions on management policies. Thus, such corporate governance reforms not only have implications for audit quality

* The authors are respectively from the University of Manchester, University of Nottingham and University of Hull. They would like to thank Peter Pope (editor) and an anonymous referee for their insightful comments and suggestions. The paper has also benefitted from comments received from David Hay, Claus Holm and Robert Knechel and participants at the 2007 European Auditing Research Network Symposium. (Paper received May 2008, revised version accepted November 2010)

Address for correspondence: Mahbub Zaman, Manchester Accounting \& Finance Group, Manchester Business School, University of Manchester, Crawford House, Oxford Road, Manchester M13 9PL, UK. e-mail: mahbub.zaman@mbs.ac.uk 
but also on auditor remuneration, i.e. audit fees (AF) and non-audit services fees (NASF) (Beasley et al., 2009; DeZoort et al., 2002; Knechel and Willekens, 2006; Hay et al., 2008; and Turley and Zaman, 2004).

Due to potential litigation risk and reputation impairment, firms with high-quality audit committees are more likely to discharge their responsibilities and monitor the external audit process more effectively than firms with low-quality audit committees. Therefore, AF are likely to increase due to the demand for a wider scope of audit to ensure audit quality. On the other hand, since firms with high-quality audit committees are more likely to enhance auditor independence and help strengthen the internal control process, NASF is expected to be lower. However, results of prior studies on the relationships are inconclusive (Hay et al., 2006b) and are mainly conducted in the US. Hence, we attempt to address some of the limitations in the international literature on the relationship between corporate governance and auditor remuneration.

In this paper we examine the relationship between governance quality and auditor remuneration in the UK based on a composite measure of four dimensions of audit committee effectiveness (ACE) - independence of audit committee members, financial expertise of audit committee members, the diligence (frequency of meetings) of the audit committee, and size of the audit committee. We investigate the influence of ACE on AF and NASF, using a sample of 540 company-year observations for the period 2001-2004 drawn from a sample of 135 UK FTSE-350 non-financial companies. After controlling for board of director characteristics, we find a significant positive association between ACE and AF, implying that in ensuring higher audit quality, the scope of the audit and in turn audit fees, will be increased. Contrary to expectations, the influence of ACE on NASF is significant and positive, i.e., the higher the ACE, the higher the purchase of non-audit services (NAS) by the larger audit client. The influence of ACE on NASF for smaller clients is negative as expected, but insignificant. The results may imply that for smaller clients, the audit committees are less concerned about protecting (perceived) auditor independence and thus do not restrain such companies from purchasing NAS from the incumbent auditors. Overall, our findings support regulatory initiatives aimed at improving corporate governance quality.

Our paper extends and contributes to prior literature in a number of ways. First, corporate governance regulations vary widely between countries, i.e., in some countries they are voluntary or recommended best practice while in others, they are mandatory. Our research is based on the less regulated environment of the UK and extends research conducted in a more regulated environment such as the US. Second, in most prior research audit committee effectiveness variables have been tested in isolation. In contrast, we examine the effect of audit committees based on a composite measure of four dimensions while controlling for board effectiveness dimensions as well as other company specific characteristics. Third, evidence on the effect of governance on auditor remuneration in the UK is mainly based on the earlier recommendations of the Cadbury Report (1992), whereas our paper reflects the recommendations of the Smith Report (2003) pertaining to audit committee effectiveness in the UK. Fourth, previous studies predominantly tested the influence of audit committee effectiveness on either audit fees or non-audit services fees but in this paper we looked at both types of auditor remuneration.

The remainder of the paper is structured as follows. The next section presents the background of the study and outlines the hypotheses development, followed by the research design in Section 3. Section 4 examines our two main hypotheses 
and presents our findings. Additionally, we provide regression results for sensitivity analyses. Finally in Section 5, some conclusions are drawn and the implications and limitations of the study are discussed.

\section{BACKGROUND AND HYPOTHESES DEVELOPMENT}

\section{(i) Background}

Our paper is mainly motivated by developments in corporate governance codes which provide guidelines and recommendations relating to both board of directors and audit committee structures that are intended to enhance the quality of financial reporting and external auditing. Following major financial reporting scandals - which to a large extent have been attributed to poor governance oversights - new rules have been implemented, especially in the US, to improve the quality of corporate governance (Byard et al., 2006). For instance, new corporate governance rules have been adopted by both the New York Stock Exchange (NYSE) and NASDAQ requiring all audit, compensation, and nominating committees to be fully independent. Similarly, the Sarbanes-Oxley Act of 2002 requires the audit committee to be fully independent.

In the UK, the Smith Report (2003, p. 3) which came into effect on July 1, 2003, provides guidance to company boards in making suitable arrangements for their audit committees and also to assist directors serving on audit committees in performing their role. It covers a number of aspects related to audit committees, including: its main role and responsibilities (2.1); membership and appointment (3.1-3.4); meetings (3.5-3.10); resources (3.11-3.14); remuneration (3.15), skills, experience and training (3.16-3.19), etc. It also recognises that the quality and effectiveness of the audit committee is vital for effective governance (4.2). Furthermore, the Higgs Report (2003) endorses the recommendations related to audit committees in the Smith Report and in relation to board effectiveness recommends that: at least half of the board members be independent non-executive directors (paragraph 9.5); the roles of the chairman and chief executive officer should be separated (paragraph 5.3); and non-executive directors should meet as a group at least once a year without the chairman or executive directors present (paragraph 8.8).

Despite the considerable developments in corporate governance and regulatory interest in protecting audit quality, significant variation in governance requirements exists between countries and firms (Doidge et al., 2007). There are indeed differences between the US, Australia and the UK environment in terms of corporate governance (see Beekes and Brown, 2006; Collett and Hrasky, 2005; Conyon, 2000; and Doidge et al., 2007): for instance, while the UK and Australia have adopted the voluntary approach of 'comply or explain', corporate governance in the US is mandated by the Sarbanes Oxley Act 2002 (see the Appendix). Henry (2008), commenting on the differences in corporate governance between Australia and the UK, notes that UK companies are subject to more stringent requirements in relation to board meetings, limits on directors' outside workloads, shareholder approval of long-term executive director incentive schemes, and audit committee structure and responsibilities. There is also greater variation in board composition in the UK than in the US, and audit committees are not mandatory in the UK (Peasnell et al., 2005). Collier and Zaman (2005) also document significant differences in national requirements and recommendations relating to audit committees. 
In short, although globalisation may have induced the recommendation of some common corporate governance standards, they may not have been fully implemented (Collier and Zaman, 2005; and Khana et al., 2006). Therefore, it is not surprising to find an abundance of studies on corporate governance and auditor remuneration in the highly regulated environment of the US (see for example, Ashbaugh et al., 2003; Carcello et al., 2002; Krishnan and Visvanathan, 2009; Larcker and Richardson, 2004; and Zhang et al., 2007). In less regulated environments, including the UK and Australia, there is less evidence on the relationship between corporate governance quality and auditor remuneration.

Furthermore, in the UK, prior research on audit fees either predates the changes associated with the Smith Report (2003) and Higgs Report (2003) (for example, Collier and Gregory, 1996; O’Sullivan, 2000; and Peel and Clatworthy, 2001), or does not examine the effect of UK corporate governance (for example, Gregory and Collier, 1996; Pong, 1999; Clatworthy and Peel, 2007; and McMeeking et al., 2006). Clatworthy and Peel (2007), for instance, examine the effects of corporate failure and other new variables drawn from financial statements on external audit fees in the UK. They find that quoted and unquoted public limited companies have significantly higher audit fees than their private limited counterparts. McMeeking et al. (2006) examine whether audit firm mergers impact on audit pricing and market competitiveness as well as concentration in the UK quoted firms over the period 1985-2002. They find large audit firms significantly increased their market share over this period via mergers, but that significant fee discounting in the 1980s does not persist in the 1990s. Peel and Clatworthy (2001), examining audit fees in the pre-Cadbury (1992) period, find no significant evidence that board structure variables - including chairman/chief executive officer split and the proportion of non-executive directors on the board impact significantly on external audit fees.

The effectiveness of audit committees and their impact on audit fees and NAS fees is not well understood. One difficulty is that there are different rationales suggesting that the existence of audit committees could result in either an increase or decrease in fees. If an audit committee seeks to enhance audit quality, the impact could be an increase in audit fees. Conversely, if the existence of an audit committee enhances the strength of internal control, a reduced audit fee would be expected. Collier and Gregory (1996) examine these propositions and they find a significant positive relationship for the first, but no significant relationship for the second. They conclude that 'there is no conclusive evidence to suggest that audit committees are effective in engendering a stronger internal control environment that is reflected in reduced audit fees' (Collier and Gregory, 1996, p.195). O'Sullivan (1999), using the 1995 audit fees data for a sample of 146 UK companies, find no evidence that board and audit committee characteristics influence audit pricing. Both Collier and Gregory (1996) and O'Sullivan (1999) focus on the association between audit fees and the existence of audit committees, but not audit committee effectiveness. The study by GoodwinStewart and Kent (2006) address both the effect of audit committee existence and audit committee effectiveness on audit fees. Based on a survey of 401 Australian companies, they find higher audit fees to be related to the existence of an audit committee, more frequent committee meetings and increased use of internal audits.

The focus of extant UK studies on auditor remuneration is very different from our examination of the effect of governance quality on auditor remuneration. The introduction of codes and legislation (for instance the Smith and Higgs Reports in 
the UK and the SOX Act in the US) has changed the governance context and there is evidence that the responsibilities and authority of the audit committee have increased, in terms of power over and impact on the financial reporting and audit process (see for example, Beasley et al., 2009; and Turley and Zaman, 2007). Given the paucity of research on the relationship between audit committee effectiveness (ACE) and both AF and NASF in the UK, our paper makes an important contribution. Specifically, in this paper, we examine the influence of audit committee effectiveness (ACE) on both $\mathrm{AF}$ and NASF while controlling for board effectiveness and other company-specific characteristics.

\section{(ii) ACEffectiveness (ACE)}

ACE is not a construct that can be easily modelled for empirical testing. The major constraints being the subjectivity of the term 'effectiveness' itself, as well as the public availability of data and/or the ease with which it can be obtained. Nevertheless, four dimensions related to audit committees viz. independence of audit committee members, financial expertise of audit committee members, diligence (frequency of meetings) of the audit committee, and size of the audit committee, which have been the subject of governance codes especially in the UK (Smith Report, 2003; and Higgs Report, 2003), would act as suitable constructs in testing the effect of ACE on AF and NASF. Furthermore, the constructs are premised on their potential contribution to audit quality including ensuring that auditor independence is not compromised by the potential influence of NASF. Individually, the independence, financial expertise, diligence (frequency of meetings) and size of the audit committee are important considerations. Nonetheless, we believe it is the interactions of such dimensions that are likely to have the most impact on audit quality. Therefore, we focus on the joint effect of these dimensions as an empirical proxy for ACE.

Drawing upon the recommendations in the Smith Report (2003), we argue that for audit committees to be effective, they must at least exhibit four characteristics. First, members of the audit committee must all be independent non-executive directors. Second, the membership of the committee must include at least one director with relevant financial expertise. Third, audit committees should meet at least three times a year. ${ }^{1}$ Fourth, a minimum size of three audit committee members is required for the audit committee to function effectively. We combine the four independent variables to form the new composite construct called ACE (audit committee effectiveness). Hence, in empirically examining the influence of ACE on (a) AF and (b) NASF, we use a composite measure for ACE, i.e., all the audit committee members are independent non-executive directors, at least one member of the audit committee has financial expertise, audit committee meets at least three times a year, and the audit committee is composed of at least three members. The next section develops our hypotheses relating $\mathrm{ACE}$ to $\mathrm{AF}$ and NASF that will be tested in the study.

1 The Blue Ribbon Committee (1999) in the US recommended the minimum number of audit committee meetings to be four per annum which is understandable as it coincides with the required quarterly audit review. However, in the UK, the Smith Report only recommended a minimum number of three audit committee meetings per annum and we use this as cut-off measure of diligence. 
(iii) Hypotheses Development

\section{(a) ACE and AF}

There is a large body of international research on audit fees. In a review of the literature, Hay et al. (2006b) observe that research examining the relationship between corporate governance and audit fees is limited and preliminary evidence indicates conflicting results as to the direction of the relationship. Existing research provide two perspectives on the relationship (see Cohen et al., 2004). The first perspective is mainly based on agency theory which suggests that boards that exhibit a stronger monitoring focus will demand a higher quality audit resulting in greater audit effort by the auditor and in turn, higher fees. The other perspective treats audit fees as a by-product of a production function (Simunic, 1980). This implies that if governance mechanisms are strong, external auditors are likely to respond to the reduced risk with a decrease in audit effort which would in turn result in lower audit fees. Knechel and Willekens (2006) provide evidence in support of the demand perspective. They note that the demand for auditing is a function of the set of risks faced by individual stakeholders in an organisation and the set of control mechanisms available for mitigating those risks:

Because individual decisions about control processes and procedures may shift benefits and costs across groups of stakeholders, the net investment in auditing may increase when multiple stakeholders [such as audit committees] become involved in corporate governance decisions (p. 1345).

Consistent with their theorisation, they find that audit fee is higher when a company has an audit committee, discloses a relatively high level of financial risk management, and has a larger proportion of independent board members.

Research evidence suggests that audit committees can have a direct influence on the scope of external audits (Beasley et al., 2009; Carcello et al., 2002; Hay et al., 2008; and Turley and Zaman, 2007). In their quest to enhance audit quality, audit committees may demand greater effort from the existing external auditor (that is, a wider audit scope) which in turn, will increase the amount of AF (Abbott et al., 2003; Collier and Gregory, 1996; and Turley and Zaman, 2004). As such, we expect ACE to be associated with higher levels of $\mathrm{AF}$ as audit committees exercise greater oversight over the audit process. Hence, our first main hypothesis is as follows:

$\mathrm{H}_{1}$ : Ceteris paribus, there is a positive relationship between ACE and the level of audit fees $(\mathrm{AF})$.

Audit Committee Independence (ACI) and AF: Directors who are independent of management are expected to demand high audit quality and be more interested in reducing the likelihood of fraud and earnings management (Beasley, 1996; Hudaib and Cooke, 2005; and Peasnell et al., 2005). Thus, when all audit committee members are composed of independent non-executive directors, they will be able to exercise more power over management in demanding greater audit scope to ensure audit quality. This would consequently increase AF. Therefore, we hypothesise the relationship to be as follows:

$\mathrm{H}_{1 \mathrm{a}}$ : Ceteris paribus, there is a positive relationship between audit committee independence (ACI) and the level of audit fees (AF). 
Audit Committee Expertise (ACX) and AF: For audit committees to be effective, their membership needs to include at least one member with relevant financial expertise. Financially knowledgeable members can perform their oversight roles in the financial reporting process more effectively, such as detecting material misstatements (Raghunandan et al., 2001; Davidson et al., 2004; and DeFond et al., 2005). Krishnan (2005) provides evidence that audit committees with financial expertise have a reduced probability of being associated with the incidence of internal control problems. Research shows that audit committee members without financial experience may not be strong enough to protect audit quality (Knapp, 1987; DeZoort et al., 2002; and Turley and Zaman, 2004). Thus, we expect audit committees which have at least one member with financial expertise will be more concerned about audit quality and may influence demand for wider audit scope which will subsequently increase AF. Hence, our next hypothesis is:

$\mathrm{H}_{1 \mathrm{~b}}$ : Ceteris paribus, there is a positive relationship between audit committee expertise (ACX) and the level of audit fees (AF).

Audit Committee Meetings (ACM) and AF: For an audit committee to be effective, it must be active. Previous research has established the importance of active committees for the oversight of the financial reporting and auditing process. Regular meetings provide opportunity for the audit committee to monitor audit quality. Meeting frequency can be a signal of audit committee diligence (Menon and Williams, 1994) and has been associated with reduced likelihood of fraud (Beasley et al., 2000; and DeZoort and Salterio, 2001). We believe that active audit committees are more likely to exert a positive influence on audit scope, which in turn will be reflected in higher AF. Therefore, we hypothesise the relationship to be as follows:

$\mathrm{H}_{1 \mathrm{c}}$ : Ceteris paribus, there is a positive relationship between audit committee meetings (ACM) and the level of audit fees (AF).

Audit Committee Size (ACS) and AF: Research suggests that a larger audit committee is more likely to enhance its status and power within an organisation, and demand higher audit quality (Kalbers and Fogarty, 1993). Furthermore, Pincus et al. (1989) suggest that larger audit committees will be more likely to discover potential problems through increase in resources which would enable them to help improve the quality of its oversight. Thus, we expect that a large audit committee is more likely than a small one to improve the quality of internal controls. This is a result of enhanced status and increased resources that will make the audit committee more effective in fulfilling its monitoring role. This will have implications on AF and as such, we hypothesise the following:

$\mathrm{H}_{1 \mathrm{~d}}$ : Ceteris paribus, there is a positive relationship between audit committee size (ACS) and the level of audit fees (AF).

\section{(b) ACE and NASF}

The provision of NAS has been argued in many studies to impair auditor independence (see for example Barkess and Simnett, 1994; Beattie et al., 1999; Firth, 1997, and 2002; Hay et al., 2006a; and Sharma and Shidhu, 2001). The joint provision of audit and NAS creates a potential perception that auditors might compromise their 
independence and be unduly driven by a desire to maintain their clients in order to preserve their audit and NAS fee income. Effective audit committees are averse to high levels of NASF due to potential threat to auditor independence (Abbott and Parker, 2000; DeZoort et al., 2002; Gaynor et al., 2006; and Turley and Zaman, 2004). We posit that ACE will have a negative association with NASF. Hence, our second main hypothesis is as follows:

$\mathrm{H}_{2}$ : Ceteris paribus, there is a negative relationship between ACE and the level of non-audit services fees (NASF).

Audit Committee Independence (ACI) and NASF: Directors who are independent of management will be more concerned with audit quality and threats impairing auditor independence. Prior research suggests that audit committees which are independent of management are likely to be more concerned about protecting auditor independence and thus be averse to high levels of NAS (Bedard and Paquette, 2008; and Gaynor et al., 2006). Abbott et al. (2003) note that independent audit committee's concern for auditor independence can have a direct or indirect effect on the purchase of NAS. In the case of the latter, although an independent audit committee may not be directly involved in the purchase decision but it is possible that management may voluntarily reduce the level of NAS in anticipation of the potential concern of the independent audit committee. For this reason, we hypothesise the relationship to be as follows:

$\mathrm{H}_{2 \mathrm{a}}$ : Ceteris paribus, there is a negative relationship between audit committee independence (ACI) and the level of non-audit services fees (NASF).

Audit Committee Expertise (ACX) and NASF: Audit committee members with financial expertise are more likely to be able to deal with the complexities of financial reporting, understand auditor judgments and support the auditor in auditor-management disputes than members without such knowledge (Bedard and Paquette, 2008; Davidson et al., 2004; DeFond et al., 2005; DeZoort and Salterio, 2001; and Kalbers and Fogarty, 1993). Accordingly, the existence of financial experts on the committee - through strict monitoring and awareness of the deficiencies in the system - would not make it easy for management to seek NAS. The result is that the amount of NASF will be reduced (Gaynor et al., 2006). Hence, our next hypothesis is:

$\mathrm{H}_{2 \mathrm{~b}}$ : Ceteris paribus, there is a negative relationship between audit committee expertise (ACX) and the level of non-audit services fees (NASF).

Audit Committee Meetings (ACM) and NASF: When members of the audit committees meet regularly, it is a signal that they are active in conducting their due diligence. This implies that they are able to exert positive influence on the audit scope which means that external auditors will have to put in more effort. In other words, when audit committees demand higher effort from external auditors, the lesser will be the need for management to buy NAS (Abbott et al., 2003; DeZoort et al., 2002; and Turley and Zaman, 2004). Thus, we hypothesise the relationship to be as follows:

$\mathrm{H}_{2 \mathrm{c}}$ : Ceteris paribus, there is a negative relationship between audit committee meetings (ACM) and the level of non-audit services fees (NASF).

Audit Committee Size (ACS) and NASF: Since it is difficult to recruit all members with financial expertise, larger audit committees tend to have members with both financial 
and non-financial expertise. The inclusion of members with wealth of experience from other fields will help to oversee whether there is a genuine need for outsourcing consultancy services (Gaynor et al., 2006) besides helping to monitor the quality of audit. Larger audit committees will be able to perform their role better through sharing of knowledge, which will benefit the company from having to otherwise seek NAS to resolve problems (Archambeault and DeZoort, 2001). This will subsequently reduce NASF and therefore, we hypothesise the following:

$\mathrm{H}_{2 \mathrm{~d}}$ : Ceteris paribus, there is a negative relationship between audit committee size (ACS) and the level of non-audit services fees (NASF).

\section{(c) Control Variables}

We recognise that various explanatory factors suggested in the literature may intervene in the process and have complex relations with AF and NASF. Thus, we include in our two main models a number of control variables that are missing in the GoodwinStewart and Kent (2006) study but which are deemed important in AF and NASF literature.

Our control variables can be further categorised into board effectiveness and company-related factors. They may potentially have an influence on the level of AF and NASF. By incorporating board effectiveness variables into our model, we are able to further examine whether ACE has any influence on auditor remuneration. Here we note that the US study of Carcello et al. (2002) on board characteristics and AF based on a sample of Fortune 1000 companies with fiscal years ending between April 1992 and March 1993, find that 'audit committee variables provide no incremental explanatory power when the board characteristics are included in the model' (p.379). Their results show that none of the audit committee variables is significantly related to audit fees. We find the Carcello et al. (2002) result puzzling. Our belief is that since audit committees have specific oversight responsibility for financial reporting and external audits, after controlling for the board of directors variables, our test variable ACE will have a significant positive association with AF and a negative significant association with NASF. We explore both board effectiveness and company-related control variables below.

Board Effectiveness: Our first control variable related to board effectiveness is the number of board meetings (BM). Similar to our discussion earlier about audit committee meetings, the number of board meetings (BM) can indicate the level of diligence exercised by the board of directors. Carcello et al. (2002) confirm that high frequency of board meetings could indicate a higher level of control in the company. Thus, it could be associated with higher AF and lower NASF.

The composition of the board of directors is also a potentially important factor affecting audit quality. Hence, we also control for the proportion of non-executive directors (NED) on the board. A high proportion of NEDs suggests better governance because such directors have an interest in protecting their own reputation and avoiding potential financial loss that may result from litigation (Young, 2000). This would be reflected in a positive association with $\mathrm{AF}$ and a negative association with NASF.

We control for a third factor relating to board of directors - duality (whether the board chair is also the company's chief executive officer) that may potentially 
influence audit quality. As noted by Jensen (1993) and Collier and Gregory (1996), role duality may exert undue influence on the board and can have a potentially adverse influence on audit quality and audit committee activities, respectively. This may increase $\mathrm{AF}$ as it requires higher control of risk and higher audit effort (Tsui et al., 2001). In contrast, duality may weaken auditor independence and increase NASF.

Company-specific factors: Finally, following the literature on AF, we control for a number of company related variables that have been hypothesised to be associated with auditor remuneration. First of all, we look at auditor type (BIG4). It is suggested that firms with internal control problems are less likely to hire a BIG4 auditor because they might be financially constrained and consider BIG4 firms to be expensive. Equally, such firms might also be avoided by the BIG4 auditors because they are perceived as being risky and may expose the BIG4 to potential litigation. Hence, we can expect BIG4 to be positively related to AF and NASF.

The next control variable is company size (SIZE). Large client firms differ from their smaller counterparts in their need for both audit and NAS. Large firms require higher audit quality and, as such, we can expect them to have higher AF. Their operations are also often more complex and will have a greater need for NAS. In other words, larger firms will be positively related to both AF and NASF.

Our third company-related control variable is company complexity using the number of subsidiaries as a proxy (SUBS). Firms with a greater number of subsidiaries are more complex and may have weaker internal control and greater in-house capabilities, which means higher AF and NASF. Hence, company complexity will be positively related to both AF and NASF.

Level of risk, using leverage (LEV) as a proxy, is our fourth company-related control variable. Firms with higher leverage require careful monitoring to protect themselves from business and financial risk and, as such, will be positively related to both AF and NASF.

The fifth control variable is related to mergers and acquisition activities (ACQ). Since it may take some time for a firm that has recently been involved in mergers and acquisitions to integrate different internal control systems, the firm is also more likely to have internal control problems that may require higher audit and consulting services (Firth, 1997). Therefore, we can expect a positive relationship between ACQ and AF as well as NASF.

The sixth control variable concerns the situation where a company incurs a loss (LOSS) in the previous two years. A poorly performing company is expected to have internal control problems and is also more likely to demand more external consulting services to improve profitability (Parkash and Venable, 1993; DeFond et al., 2002; and Whisenant et al., 2003). Thus, we can expect a positive relationship with AF and NASF.

The concentration of ownership based on the number of shareholders with $5 \%$ or more shareholdings (NSH5) is our next control variable. As part of their active monitoring, large shareholders may put less demand on audit effort and induce management to reduce purchase of NAS from external auditors if they perceive that the provision of significant NAS would potentially impair auditor objectivity in certification functions. Hence, we can expect a negative relationship with AF and NASF.

Finally, we control for industry (INDY) and year (T). Level of risk and business complexity differs between industries and at different times. Thus, we expect a relationship between the dependent variables and type of industry and time. 
Table 1

Population and Sample Size Classified by Industrial Sector and the Association between ACE and Company Size

\begin{tabular}{|c|c|c|c|c|c|}
\hline $\begin{array}{l}\text { Panel A } \\
\text { Sector [1] }\end{array}$ & No. of Co. [2] & $\%[3]$ & $\begin{array}{l}\text { No. of Co. } \\
\text { Required [4] }\end{array}$ & $\%[5]$ & No. of Co. Included [6] \\
\hline General Industrials & 100 & 39 & 60 & 39 & 50 \\
\hline Services & 131 & 51 & 79 & 51 & 70 \\
\hline Consumer Goods & 18 & 7 & 11 & 7 & 10 \\
\hline Mineral Extraction & 5 & 2 & 3 & 2 & 3 \\
\hline Utilities & 3 & 1 & 2 & 1 & 2 \\
\hline Total & 257 & 100 & 155 & 100 & 135 \\
\hline Panel B & \multirow{2}{*}{\multicolumn{2}{|c|}{ Small }} & \multirow{2}{*}{\multicolumn{2}{|c|}{ Large }} & \\
\hline Company Size & & & & & Total \\
\hline NEAC & \multicolumn{2}{|c|}{$248(54.6 \%)$} & \multicolumn{2}{|c|}{$206(45.4 \%)$} & $454(100 \%)$ \\
\hline ACE & \multicolumn{2}{|c|}{$23(26.7 \%)$} & \multicolumn{2}{|c|}{$63(73.3 \%)$} & $86(100 \%)$ \\
\hline Total & \multicolumn{2}{|c|}{$271(50.2 \%)$} & \multicolumn{2}{|c|}{$269(49.8 \%)$} & $540(100 \%)$ \\
\hline
\end{tabular}

Notes:

$\mathrm{NEAC}=$ Non Effective Audit Committees.

$\mathrm{ACE}=\mathrm{AC}$ Effectiveness $=\mathrm{ACM}>=3=1, \mathrm{ACX}=1, \mathrm{ACI}=1 \& \mathrm{ACS}>=3=1$.

\section{RESEARCH DESIGN}

\section{(i) Data Collection}

The population of our study is the UK FTSE-350 which represents a good mix of large and relatively small UK companies. The period covered is 2001 to 2004 inclusive. We removed all companies in the financial sector due to differences in regulatory environment, leaving us with a population of 257 companies, from which a sample size of 155 was selected $(60 \%) .^{2}$ The LSE classification of industries ${ }^{3}$ was consolidated and five industry categories were derived. As the number of companies in each industry group is not the same, proportionate stratified sampling was then used to derive the size of each stratum (see Column 4 in Table 1 Panel A). However, 20 companies were eliminated from the sample because of missing data; giving a final sample of 135 in five sectors (see Column 6 in Table 1 Panel A). Based on our definitions of audit committee effectiveness (ACE), our sample consists of $86(16 \%)$ companies which are considered as having effective audit committees. Of these companies, 23 are small companies and 63 are large companies (see Table 1 Panel B). ${ }^{4}$

The final sample is considered to be representative of non-financial UK FTSE-350 companies. The study is a longitudinal survey of four years and after adjusting for the

2 The sample size selected is based on the table of general scientific guidelines for sample size decisions provided by Sekaran (1992).

3 Waterlow Stock Exchange Yearbook 2005.

4 It is not surprising to find low but significant number of cases fulfilling all four criteria of effectiveness based on Smith's recommendations as it came into effect only in 2003. Further analysis of the data indicates that the criteria which are least fulfilled are the requirement for audit committees to have at least three meetings (426 out of 540 cases or $79 \%$ having less than three meetings), followed by the requirement to have at least one financial expertise on the audit committee (157 out of 540 cases or $29 \%$ not having any financial expertise). 
entry/exit of companies, the total number of company year observations is $540 .{ }^{5}$ Data regarding $\mathrm{AF}$ and NASF were obtained manually from the notes to the accounts. We sourced audit committee and board characteristics data mostly from the corporate governance and audit committee reports in each of the companies' annual reports. All financial data have been obtained from FAME (Financial Analysis Made Easy) database.

\section{(ii) Variable Measurement and Model Specification}

\section{(a) Dependent Variables}

Consistent with previous studies on $\mathrm{AF}$, we use a single equation approach to test our two main hypotheses relating to the influence of ACE on AF and NASF. We use a number of ordinary least squares (OLS) regression models to help us explore further the various relationships between ACE and AF and NASF, while controlling for other variables.

\section{(b) Independent Variables}

The main independent variable of interest is ACE (audit committee effectiveness) which is a composite measure consisting of audit committee independence (ACI), audit committee financial expertise (ACX), frequency of audit committee meetings (ACM) and size of audit committee (ACS). The four constructs included in the composite ACE measure are based on the guidelines of the Smith Report (2003). Audit committee independence (ACI) is a dichotomous variable with 1 denoting all members of the audit committee are independent non-executive directors (Smith Report, paragraph 3.1) as defined in the Higgs Report. ${ }^{6}$ Audit committee expertise (ACX) is a dichotomous variable with 1 denoting at least one member of the committee having financial expertise (Smith Report, paragraph 3.16). ${ }^{7}$ Frequency of audit committee meetings (ACM) and size of audit committee (ACS) are both continuous variables. However, for the purpose of inclusion in the composite measure of ACE, a cut-off of three or more meetings (Smith Report, paragraph 3.5) and three or more members (Smith Report, paragraph 3.1) are used. Hence, ACM is coded 1 when the number of meetings is three or more and 0 otherwise. Similarly, ACS is coded 1 when the number of members on the audit committee is three or more and 0 otherwise.

ACE is thus a dichotomous variable equal to 1 when (i) the audit committee membership consists of all independent non-executive directors, (ii) at least one member of the audit committee has financial expertise, (iii) audit committee members meet at least three times a year, and (iv) audit committee comprised of at least three members.

5 Durbin-Watson test was conducted and results indicate no serial correlation problems.

6 See Higgs Report (2003) 'Review of the role and effectiveness of non-executive directors' and paragraph A.3.4 in the revised Code proposed by Higgs. Paragraph A.3.4 reads 'A non-executive director is considered independent when the board determines that the director is independent in character and judgement, and there are no relationships or circumstances which could affect, or appear to affect, the director's judgement' (p.81).

7 The biographical data disclosed in the annual report for members of the audit committee was perused to identify those with accounting, finance or professional accounting qualifications. 
(c) Control Variables

Board characteristics related control variables included in our models are: number of board meetings (BM), the proportion of NEDs on the board (NED), ${ }^{8}$ and role duality (DUALITY). We also control for company-related ownership structure, that is, the number of shareholders holding $5 \%$ or more of the company's shares (NSH5). Finally, other company related control variables include the size of the company (SIZE), leverage (LEV), complexity (lnSUBS), type of auditor (BIG4), type of industry (INDY), year (T), and whether in the last two years the company made a loss (LOSS), or an acquisition (ACQ).

(d) Models

We test our two main hypotheses using the following models:

Model 1: The association between ACE and AF

$$
\begin{aligned}
\ln \mathrm{AF}_{i t}= & \beta_{0}+\sum_{i=1}^{4} \delta_{i t x}(\mathrm{ACE})+\beta_{2} \mathrm{NED}_{i t}+\beta_{3} \mathrm{BM}_{i t}+\beta_{4} \mathrm{DUALITY}_{i t}+\beta_{5} \mathrm{BIG}_{i t}+\beta_{6} \mathrm{SIZE}_{i t} \\
& +\beta_{7} \ln \mathrm{SUBS}_{i t}+\beta_{8} \mathrm{LEV}_{i t}+\beta_{9} \mathrm{ACQ}_{i t}+\beta_{10} \mathrm{LOSS}_{i t}+\beta_{11} \mathrm{NSH}_{i t} \\
& +\sum_{i=1}^{5} \delta_{i t x}(\mathrm{INDY})+\beta_{12} \mathrm{~T}_{i t} .
\end{aligned}
$$

Model 2: The association between ACE and NASF

$$
\begin{aligned}
\mathrm{NNASF}_{i t}= & \beta_{0}+\sum_{i=1}^{4} \delta_{i t x}(\mathrm{ACE})+\beta_{2} \mathrm{NED}_{i t}+\beta_{3} \mathrm{BM}_{i t}+\beta_{4} \mathrm{DUALITY}_{i t}+\beta_{5} \mathrm{BIG}_{i t}+\beta_{6} \mathrm{SIZE}_{i t} \\
& +\beta_{7} \ln \mathrm{SUBS}_{i t}+\beta_{8} \mathrm{LEV}_{i t}+\beta_{9} \mathrm{ACQ}_{i t}+\beta_{10} \mathrm{LOSS}_{i t}+\beta_{11} \mathrm{NSH}_{i t}+\sum_{i=1}^{5} \delta_{i t x}(\mathrm{INDY}) \\
& +\beta_{12} \mathrm{~T}_{i t}+\varepsilon_{m 1} .
\end{aligned}
$$

Where:

Independent variables

$\ln \mathrm{AF}=$ Natural logarithm of audit fees.

NNASF $=$ Normal score of non-audit services fees.

Dependent variables:

$\mathrm{ACE}=$ Audit Committee Effectiveness. An audit committee is effective when $[(\mathrm{ACI}=1)+$ $(\mathrm{ACX}=1)+(\mathrm{ACM} \geq 3=1)+(\mathrm{ACS} \geq 3=1)]$.

ACI = Audit committee's independence. Dichotomous with 1 if all AC members are independent non-executive directors, 0 otherwise.

8 We classified independence of non-executive directors based on the definitions in the Higgs Report (2003) 'Review of the role and effectiveness of non-executive directors.' Refer to footnote 6. 
ACX = Audit committee's financial expertise. Dichotomous with 1 if the audit committee contains a member with financial expertise, 0 otherwise.

ACM = Frequency of audit committee meetings held during the financial year.

ACS $=$ Size of audit committee.

NED = The proportion of non-executive directors to total number of directors on the board of the company.

$\mathrm{BM}=$ Number of board meetings held in the financial year.

DUALITY $=$ Chief executive officer is also chair of the board. A dummy variable equals to 1 if the chief executive concurrently holds the position of chairman, 0 otherwise.

BIG4 = BIG4 as auditor. A dummy variable equals to 1 if the company employs a BIG4 audit firm as their auditor, 0 otherwise.

SIZE $=$ SIZE of company based on the natural logarithm of total assets.

lnSUBS = Complexity of the business using natural logarithm of number of subsidiaries as proxy.

LEV = Leverage of the company measured by the ratio of long-term debt to total assets.

ACQ $=$ Whether the company made an acquisition in the two previous financial years. A dummy variable equals to 1 if the company made an acquisition, 0 otherwise.

LOSS = Whether the company made a loss in the two previous financial years. A dummy variable equals to 1 if the company made a loss in the two previous financial years, 0 otherwise.

NSH5 $=$ Number of shareholders with $\geq 5 \%$ shareholdings in the company.

INDY = Type of industry. Dummy variables for each of the following industry classifications: General Industrials, Services, Consumer Goods, Mineral Extraction, Utilities.

$\mathrm{T}=$ = Time. Dummy variables for each year: 2001, 2002, 2003, 2004.

$\varepsilon_{m 1} \quad$ Standardised residuals of Model 1 .

We first test our independent variable of interest (ACE) with the dependent variable, logarithm of audit fees (lnAF) while controlling for other independent variables. We then run the second model using normal score of non-audit services fees (NNASF). Since most of the factors influencing lnAF also influence NNASF and the relationships between AF, NASF and the other explanatory variables suggested in the literature are complex, we incorporated the standardised residuals $\left(\varepsilon_{m 1}\right)$ of $\ln A F$ from Model 1 into Model 2 to control for the incremental effect of AF on the level of NASF.

\section{EMPRICAL RESULTS AND ANALYSIS}

\section{(i) Descriptive Statistics}

Table 2 provides the descriptive statistics viz. mean, standard deviation, minimum, maximum, standardised skewness and kurtosis, for the dependent (Panel A) and independent variables (Panels B and C) used in our models for each year as well as for pooled data. The mean for audit fees has increased over the four year period, but the mean for NASF has decreased over the same period. ${ }^{9}$

The means related to frequency of meetings of audit committees (ACM), as well as board meetings (BM), have increased from 2.6 to 3.4 times and 8.7 to 9 times respectively from 2001 to 2004. This suggests that both audit committees and

9 Note the UK does not follow the US Sarbanes Oxley Act's requirement of banning dual provision of audit and NAS by incumbent audit firm. 
Table 2

Descriptive Statistics of Dependent and Independent Variables

\begin{tabular}{|c|c|c|c|c|c|}
\hline Variables & $\begin{array}{c}\text { All Mean } \\
\text { Std.Dev. } \\
\text { Min. } \\
\text { Max. } \\
\text { Std.Skew } \\
\text { Std.Kurt. }\end{array}$ & $\begin{array}{c}\text { Mean } 2001 \\
\text { Std.Dev. } \\
\text { Min. } \\
\text { Max. } \\
\text { Std.Skew } \\
\text { Std.Kurt. }\end{array}$ & $\begin{array}{c}\text { Mean } 2002 \\
\text { Std.Dev. } \\
\text { Min. } \\
\text { Max. } \\
\text { Std.Skew } \\
\text { Std.Kurt. }\end{array}$ & $\begin{array}{c}\text { Mean } 2003 \\
\text { Std.Dev. } \\
\text { Min. } \\
\text { Max. } \\
\text { Std.Skew } \\
\text { Std.Kurt. }\end{array}$ & $\begin{array}{c}\text { Mean } 2004 \\
\text { Std.Dev. } \\
\text { Min. } \\
\text { Max. } \\
\text { Std.Skew } \\
\text { Std.Kurt. }\end{array}$ \\
\hline \multicolumn{6}{|l|}{ Panel A: Dependent } \\
\hline \multirow[t]{6}{*}{ Auditfees (AF) } & 202,489 & 183,641 & 192,578 & 208,870 & 224,589 \\
\hline & 158,241 & 154,421 & 149,915 & 163,211 & 163,587 \\
\hline & 18,000 & 18,000 & 19,000 & 20,000 & 27,762 \\
\hline & $1,100,000$ & 900,000 & 800,000 & $1,000,000$ & $1,100,000$ \\
\hline & 2.06 & 2.06 & 1.53 & 2.12 & 2.51 \\
\hline & 6.89 & 5.94 & 2.76 & 7.03 & 10.86 \\
\hline \multirow{6}{*}{$\begin{array}{l}\text { Non-audit services } \\
\text { fees (NAS) }\end{array}$} & 211,397 & 280,733 & 199,306 & 179,232 & 187,345 \\
\hline & 304,397 & 478,868 & 238,632 & 207,631 & 197,051 \\
\hline & 0.00 & 2,000 & 0.00 & 0.00 & 4,000 \\
\hline & $2,900,000$ & $2,900,000$ & $1,103,000$ & $1,252,000$ & $1,057,000$ \\
\hline & 4.13 & 3.41 & 1.95 & 2.59 & 1.89 \\
\hline & 25.81 & 13.58 & 3.63 & 9.49 & 4.71 \\
\hline \multicolumn{6}{|c|}{ Panel B: Independent (continuous) } \\
\hline \multirow{6}{*}{$\begin{array}{l}\text { No. of audit } \\
\text { committees } \\
\text { meetings (ACM) }\end{array}$} & 2.92 & 2.59 & 2.67 & 2.99 & 3.43 \\
\hline & 0.88 & 0.66 & 0.69 & 0.79 & 1.08 \\
\hline & 2.00 & 2.00 & 2.00 & 2.00 & 2.00 \\
\hline & 8.00 & 4.00 & 4.00 & 5.00 & 8.00 \\
\hline & 1.49 & 0.70 & 0.55 & 0.57 & 1.85 \\
\hline & 5.07 & -0.57 & -0.79 & 0.11 & 5.38 \\
\hline \multirow{6}{*}{$\begin{array}{l}\text { Audit committee } \\
\text { size (ACS) }\end{array}$} & 3.26 & 3.39 & 3.33 & 3.23 & 3.10 \\
\hline & 0.82 & 0.91 & 0.89 & 0.79 & 0.65 \\
\hline & 2.00 & 2.00 & 2.00 & 2.00 & 2.00 \\
\hline & 6.00 & 6.00 & 5.00 & 5.00 & 5.00 \\
\hline & 0.47 & 0.36 & 0.26 & 0.48 & 0.56 \\
\hline & 0.02 & -0.10 & -0.62 & 0.02 & 1.05 \\
\hline \multirow{6}{*}{$\begin{array}{l}\text { No. of board } \\
\text { meetings (BM) }\end{array}$} & 8.78 & 8.74 & 8.58 & 8.81 & 8.99 \\
\hline & 2.59 & 2.52 & 2.49 & 2.57 & 2.77 \\
\hline & 4.00 & 4.00 & 4.00 & 4.00 & 4.00 \\
\hline & 19.00 & 12.00 & 12.00 & 17.00 & 19.00 \\
\hline & 0.11 & -0.24 & -0.16 & 0.21 & 0.45 \\
\hline & -0.04 & -1.12 & -1.14 & 0.03 & 1.20 \\
\hline \multirow{6}{*}{$\begin{array}{l}\text { Proportion of } \\
\text { non-exec } \\
\text { directors on } \\
\text { board (NED) }\end{array}$} & 0.53 & 0.51 & 0.53 & 0.53 & 0.54 \\
\hline & 0.12 & 0.13 & 0.13 & 0.12 & 0.10 \\
\hline & 0.22 & 0.22 & 0.25 & 0.29 & 0.27 \\
\hline & 0.83 & 0.75 & 0.83 & 0.80 & 0.78 \\
\hline & -0.21 & -0.37 & -0.07 & -0.02 & -0.20 \\
\hline & -0.17 & -0.56 & -0.43 & -0.04 & 0.24 \\
\hline \multirow{6}{*}{$\begin{array}{l}\text { Number of } \\
\text { subsidiaries } \\
\text { (SUBS) }\end{array}$} & 14.91 & 16.06 & 14.93 & 14.07 & 14.60 \\
\hline & 13.80 & 15.93 & 15.46 & 11.83 & 11.50 \\
\hline & 1.00 & 1.00 & 1.00 & 1.00 & 1.00 \\
\hline & 87.00 & 84.00 & 87.00 & 63.00 & 60.00 \\
\hline & 2.67 & 2.62 & 3.07 & 2.15 & 1.81 \\
\hline & 9.90 & 8.26 & 11.94 & 6.55 & 5.00 \\
\hline
\end{tabular}


Table 2 (Continued)

\begin{tabular}{|c|c|c|c|c|c|}
\hline Variables & $\begin{array}{l}\text { All Mean } \\
\text { Std.Dev. } \\
\text { Min. } \\
\text { Max. } \\
\text { Std.Skew } \\
\text { Std.Kurt. }\end{array}$ & $\begin{array}{l}\text { Mean } 2001 \\
\text { Std.Dev. } \\
\text { Min. } \\
\text { Max. } \\
\text { Std.Skew } \\
\text { Std.Kurt. }\end{array}$ & $\begin{array}{c}\text { Mean } 2002 \\
\text { Std.Dev. } \\
\text { Min. } \\
\text { Max. } \\
\text { Std.Skew } \\
\text { Std.Kurt. }\end{array}$ & $\begin{array}{c}\text { Mean } 2003 \\
\text { Std.Dev. } \\
\text { Min. } \\
\text { Max. } \\
\text { Std.Skew } \\
\text { Std.Kurt. }\end{array}$ & $\begin{array}{c}\text { Mean } 2004 \\
\text { Std.Dev. } \\
\text { Min. } \\
\text { Max. } \\
\text { Std.Skew } \\
\text { Std.Kurt. }\end{array}$ \\
\hline $\begin{array}{l}\text { No. of shareholders } \\
\text { with } \geq 5 \% \\
\text { s/holdings } \\
\text { (NSH5) }\end{array}$ & $\begin{array}{r}5.81 \\
2.29 \\
1.00 \\
13.00 \\
0.54 \\
0.00\end{array}$ & $\begin{array}{r}5.59 \\
2.19 \\
2.00 \\
13.00 \\
0.89 \\
1.36\end{array}$ & $\begin{array}{r}5.79 \\
2.41 \\
1.00 \\
13.00 \\
0.59 \\
0.17\end{array}$ & $\begin{array}{r}5.72 \\
2.29 \\
1.00 \\
11.00 \\
0.33 \\
-0.55\end{array}$ & $\begin{array}{r}6.15 \\
2.27 \\
1.00 \\
11.00 \\
0.43 \\
-0.58\end{array}$ \\
\hline $\begin{array}{l}\text { Company size based } \\
\text { on total assets } \\
\text { (SIZE) }\end{array}$ & $\begin{array}{r}164,485,094 \\
158,822,847 \\
6,912,380 \\
852,000,000 \\
2.13 \\
4.79\end{array}$ & $\begin{array}{r}163,173,397 \\
164,584,720 \\
14,167,933 \\
689,400,000 \\
1.80 \\
2.56\end{array}$ & $\begin{array}{r}167,203,899 \\
169,809,521 \\
7,210,000 \\
810,117,000 \\
2.10 \\
4.47\end{array}$ & $\begin{array}{r}158,859,754 \\
149,609,785 \\
6,912,380 \\
782,300,000 \\
2.29 \\
6.13\end{array}$ & $\begin{array}{r}168,683,893 \\
152,072,494 \\
7,551,277 \\
852,000,000 \\
2.48 \\
7.37\end{array}$ \\
\hline $\begin{array}{l}\text { Leverage based on } \\
\text { ratio of long-term } \\
\text { to total assets } \\
\text { (LEV) }\end{array}$ & $\begin{array}{l}0.15 \\
0.17 \\
0.00 \\
0.73 \\
1.37 \\
1.42\end{array}$ & $\begin{array}{l}0.16 \\
0.16 \\
0.00 \\
0.72 \\
1.26 \\
1.46\end{array}$ & $\begin{array}{l}0.16 \\
0.17 \\
0.00 \\
0.73 \\
1.20 \\
0.71\end{array}$ & $\begin{array}{l}0.13 \\
0.16 \\
0.00 \\
0.70 \\
1.80 \\
3.38\end{array}$ & $\begin{array}{l}0.17 \\
0.19 \\
0.00 \\
0.79 \\
1.27 \\
0.86\end{array}$ \\
\hline Variables & $\begin{array}{l}\text { All Mean } \\
\text { Std.Dev. } \\
\text { Min. } \\
\text { Max. }\end{array}$ & $\begin{array}{c}\text { Mean } 2001 \\
\text { Std.Dev. } \\
\text { Min. } \\
\text { Max. }\end{array}$ & $\begin{array}{c}\text { Mean } 2002 \\
\text { Std.Dev. } \\
\text { Min. } \\
\text { Max. }\end{array}$ & $\begin{array}{l}\text { Mean } 2003 \\
\text { Std.Dev. } \\
\text { Min. } \\
\text { Max. }\end{array}$ & $\begin{array}{l}\text { Mean } 2004 \\
\text { Std.Dev. } \\
\text { Min. } \\
\text { Max. }\end{array}$ \\
\hline \multicolumn{6}{|c|}{ Panel C: Independent (binary) } \\
\hline $\begin{array}{l}\text { Audit committee } \\
\text { effectiveness } \\
\text { (ACE) }\end{array}$ & $\begin{array}{l}0.16 \\
0.37 \\
0.00 \\
1.00\end{array}$ & $\begin{array}{l}0.12 \\
0.32 \\
0.00 \\
1.00\end{array}$ & $\begin{array}{l}0.16 \\
0.36 \\
0.00 \\
1.00\end{array}$ & $\begin{array}{l}0.20 \\
0.40 \\
0.00 \\
1.00\end{array}$ & $\begin{array}{l}0.16 \\
0.37 \\
0.00 \\
1.00\end{array}$ \\
\hline $\begin{array}{l}\text { Audit committee } \\
\text { financial } \\
\text { expertise } \\
\text { (ACX) }\end{array}$ & $\begin{array}{l}0.71 \\
0.46 \\
0.00 \\
1.00\end{array}$ & $\begin{array}{l}0.59 \\
0.49 \\
0.00 \\
1.00\end{array}$ & $\begin{array}{l}0.70 \\
0.46 \\
0.00 \\
1.00\end{array}$ & $\begin{array}{l}0.74 \\
0.44 \\
0.00 \\
1.00\end{array}$ & $\begin{array}{l}0.80 \\
0.40 \\
0.00 \\
1.00\end{array}$ \\
\hline $\begin{array}{l}\text { Audit committee } \\
\text { independence } \\
\text { (ACI) }\end{array}$ & $\begin{array}{l}0.97 \\
0.18 \\
0.00 \\
1.00\end{array}$ & $\begin{array}{l}0.94 \\
0.24 \\
0.00 \\
1.00\end{array}$ & $\begin{array}{l}0.96 \\
0.21 \\
0.00 \\
1.00\end{array}$ & $\begin{array}{l}0.99 \\
0.12 \\
0.00 \\
1.00\end{array}$ & $\begin{array}{l}0.99 \\
0.12 \\
0.00 \\
1.00\end{array}$ \\
\hline $\begin{array}{l}\text { Audit committee } \\
\text { size }(A C S)^{\mathrm{a}}\end{array}$ & $\begin{array}{l}0.34 \\
0.47 \\
0.00 \\
1.00\end{array}$ & $\begin{array}{l}0.44 \\
0.50 \\
0.00 \\
1.00\end{array}$ & $\begin{array}{l}0.39 \\
0.49 \\
0.00 \\
1.00\end{array}$ & $\begin{array}{l}0.30 \\
0.46 \\
0.00 \\
1.00\end{array}$ & $\begin{array}{l}0.21 \\
0.41 \\
0.00 \\
1.00\end{array}$ \\
\hline $\begin{array}{l}\text { No. of audit } \\
\text { committees } \\
\text { meetings }(\mathrm{ACM})^{\mathrm{b}}\end{array}$ & $\begin{array}{l}0.21 \\
0.41 \\
0.00 \\
1.00\end{array}$ & $\begin{array}{l}0.11 \\
0.32 \\
0.00 \\
1.00\end{array}$ & $\begin{array}{l}0.13 \\
0.33 \\
0.00 \\
1.00\end{array}$ & $\begin{array}{l}0.21 \\
0.41 \\
0.00 \\
1.00\end{array}$ & $\begin{array}{l}0.39 \\
0.49 \\
0.00 \\
1.00\end{array}$ \\
\hline
\end{tabular}


Table 2 (Continued)

\begin{tabular}{|c|c|c|c|c|c|}
\hline Variables & $\begin{array}{l}\text { All Mean } \\
\text { Std.Dev. } \\
\text { Min. } \\
\text { Max. }\end{array}$ & $\begin{array}{l}\text { Mean } 2001 \\
\text { Std.Dev. } \\
\text { Min. } \\
\text { Max. }\end{array}$ & $\begin{array}{l}\text { Mean } 2002 \\
\text { Std.Dev. } \\
\text { Min. } \\
\text { Max. }\end{array}$ & $\begin{array}{l}\text { Mean } 2003 \\
\text { Std.Dev. } \\
\text { Min. } \\
\text { Max. }\end{array}$ & $\begin{array}{l}\text { Mean } 2004 \\
\text { Std.Dev. } \\
\text { Min. } \\
\text { Max. }\end{array}$ \\
\hline $\begin{array}{l}\mathrm{CEO} / \mathrm{MD} \text { is also } \\
\text { chair of board } \\
\text { (DUAL) }\end{array}$ & $\begin{array}{l}0.07 \\
0.26 \\
0.00 \\
1.00\end{array}$ & $\begin{array}{l}0.08 \\
0.26 \\
0.00 \\
1.00\end{array}$ & $\begin{array}{l}0.12 \\
0.32 \\
0.00 \\
1.00\end{array}$ & $\begin{array}{l}0.07 \\
0.25 \\
0.00 \\
1.00\end{array}$ & $\begin{array}{l}0.03 \\
0.17 \\
0.00 \\
1.00\end{array}$ \\
\hline $\begin{array}{l}\text { Type of auditor: } \\
\text { Big-4 (BIG4) }\end{array}$ & $\begin{array}{l}0.90 \\
0.31 \\
0.00 \\
1.00\end{array}$ & $\begin{array}{l}0.89 \\
0.31 \\
0.00 \\
1.00\end{array}$ & $\begin{array}{l}0.90 \\
0.31 \\
0.00 \\
1.00\end{array}$ & $\begin{array}{l}0.90 \\
0.31 \\
0.00 \\
1.00\end{array}$ & $\begin{array}{l}0.90 \\
0.31 \\
0.00 \\
1.00\end{array}$ \\
\hline $\begin{array}{l}\text { Company made a } \\
\text { loss in the } 2 \\
\text { previous years } \\
\text { (LOSS) }\end{array}$ & $\begin{array}{l}0.33 \\
0.47 \\
0.00 \\
1.00\end{array}$ & $\begin{array}{l}0.32 \\
0.47 \\
0.00 \\
1.00\end{array}$ & $\begin{array}{l}0.30 \\
0.46 \\
0.00 \\
1.00\end{array}$ & $\begin{array}{l}0.37 \\
0.48 \\
0.00 \\
1.00\end{array}$ & $\begin{array}{l}0.33 \\
0.47 \\
0.00 \\
1.00\end{array}$ \\
\hline $\begin{array}{l}\text { Acquisition made in } \\
\text { the } 2 \text { previous } \\
\text { years (ACQ) }\end{array}$ & $\begin{array}{l}0.48 \\
0.50 \\
0.00 \\
1.00\end{array}$ & $\begin{array}{l}0.50 \\
0.50 \\
0.00 \\
1.00\end{array}$ & $\begin{array}{l}0.54 \\
0.50 \\
0.00 \\
1.00\end{array}$ & $\begin{array}{l}0.44 \\
0.50 \\
0.00 \\
1.00\end{array}$ & $\begin{array}{l}0.42 \\
0.50 \\
0.00 \\
1.00\end{array}$ \\
\hline $\begin{array}{l}\text { No. of board } \\
\text { meetings }(\mathrm{BM})^{\mathrm{c}}\end{array}$ & $\begin{array}{l}0.51 \\
0.50 \\
0.00 \\
1.00\end{array}$ & $\begin{array}{l}0.52 \\
0.50 \\
0.00 \\
1.00\end{array}$ & $\begin{array}{l}0.50 \\
0.50 \\
0.00 \\
1.00\end{array}$ & $\begin{array}{l}0.51 \\
0.50 \\
0.00 \\
1.00\end{array}$ & $\begin{array}{l}0.52 \\
0.50 \\
0.00 \\
1.00\end{array}$ \\
\hline
\end{tabular}

Notes:

a. ACS $: 1=$ AC has at least 3 members.

b. ACM: $1=$ AC meets at least 3 times a year.

c. BM: $1=$ at least 9 board meetings a year.

boards have become more active in the latter years. The mean size of the audit committees (ACS) has shrunk slightly from 3.4 to 3.1. The means for the other two audit committee characteristics, namely, independence (ACI) and financial expertise (ACX), have both increased from 0.94 (2001) to 0.99 (2004) and 0.6 (2001) to 0.80 (2004), respectively. This indicates that almost all audit committee members were independent non-executive directors in 2004 and that the number of audit committees with at least one member having financial expertise had increased substantially in $2004,{ }^{10}$ reflecting compliance with the recommendations of the Smith Report. Only $16 \%$ of the cases in our sample are classified as having effective audit committees as is indicated by the descriptive results in Panel $\mathrm{C}$ of Table 2. The reason may be

10 It is worth noting that our mean number of companies with an audit committee expert is higher (71\%) compared to Goodwin-Stewart and Kent (2006) who find only $29 \%$ of their sample have financial expertise and Carcello et al. (2006) who report approximately half of their firms have an expert with an accounting background. The reason for the low number in the former study is due to the measure used; they used proportion of financial expertise while our study used a dichotomous measure $(1=$ having at least one member with financial expertise, 0 otherwise). The reason for the low number in the latter study is because they decomposed the definition of financial expertise into three types viz. accounting, finance and supervisory and $50 \%$ is related to only accounting expertise. If all three types of expertise are combined, then the mean is actually $90 \%$. In our case, we did not differentiate the definition of expertise and we note this as one of the limitations of our study. 
attributed mainly to the low mean of ACM where only $21 \%$ of our sample has met at least three times a year. However, looking at the means of ACM by year, it could be seen that the mean number of audit committee meetings was less than three before the Smith Report, suggesting that companies have complied with the recommended code. In other words, the UK organisational culture related to audit committee meetings seemed to follow the interim and final financial reporting cycle.

Table 3 presents the correlation matrix for the dependent and independent variables. We do not report the correlation coefficients for the industry dummies. The table shows our variable of interest, ACE, to be significantly correlated with both audit (AF) and non-audit services fees (NASF). Three audit committee effectiveness measures viz. diligence (ACM), size (ACS) and independence (ACI) are all significantly correlated with both AF and NASF with the exception of audit committee expertise (ACX). There is no multicollinearity problem with the other independent variables as the correlations are all below $0.7 .^{11}$

\section{(ii) Regression Results}

Before running the regression, we conducted analysis of residuals, plots of the studentised residuals against predicted values as well as the $Q-Q$ plot and they indicate no problems of homoscedasticity and linearity. Residuals of standard tests on skewness and kurtosis indicated some problem with the normality assumption for five of the variables and we transformed the data accordingly using natural logarithm and normal scores to get the best fit.

Table 4 presents the results from the regression of natural log of audit fees (lnAF) on the composite measure of audit committee effectiveness (ACE), the variables related to the four dimensions of ACE [independence (ACI), expertise (ACX), diligence (ACM), and size (ACS) ], board effectiveness control variables (BM, NED and DUALITY), and company-related control variables. We run the model five times, referred to as Model 1, 1a, 1b,1c and $1 \mathrm{~d}$. The $F$-value for each model is significant at the $1 \%$ level and the adjusted $R^{2}$ for each of the five models ranges between $56 \%$ and $71 \%$.

Model 1 examines the association between audit fees and the composite measure of ACE, board effectiveness and company-related control variables, including the year. $\ln \mathrm{AF}$ is positively and significantly related to ACE (at the $1 \%$ level), thus supporting our first hypothesis $\left(\mathrm{H}_{1}\right)$, as shown by the results from Model 1, reported in the third column of Table 4 . This suggests that companies with audit committees comprising of all independent non-executive directors, have at least one member with financial expertise, meet at least three times a year and have at least three members, tend to pay higher audit fees probably due to increase in the scope of audit demanded by such an audit committee to enhance audit quality. The results also indicate that two of the board effectiveness control variables, BM and DUALITY ${ }^{12}$ are both positively and negatively related to $\ln \mathrm{AF}$ at the $1 \%$ and $5 \%$ significant levels respectively. We find that for the company-related control variables, NSH5, SIZE, lnSUBS and BIG4 are all significantly related to $\ln \mathrm{AF}$ at the $1 \%$ level in the predicted direction while

11 We also calculate the variance inflation factor (VIF) and they are all within acceptable limits i.e., less than 10.0 .

12 Note that although the result for the variable duality is significantly related to audit fees, the direction is opposite to prediction i.e., results suggest that when there is role duality, audit fees will be lower. 


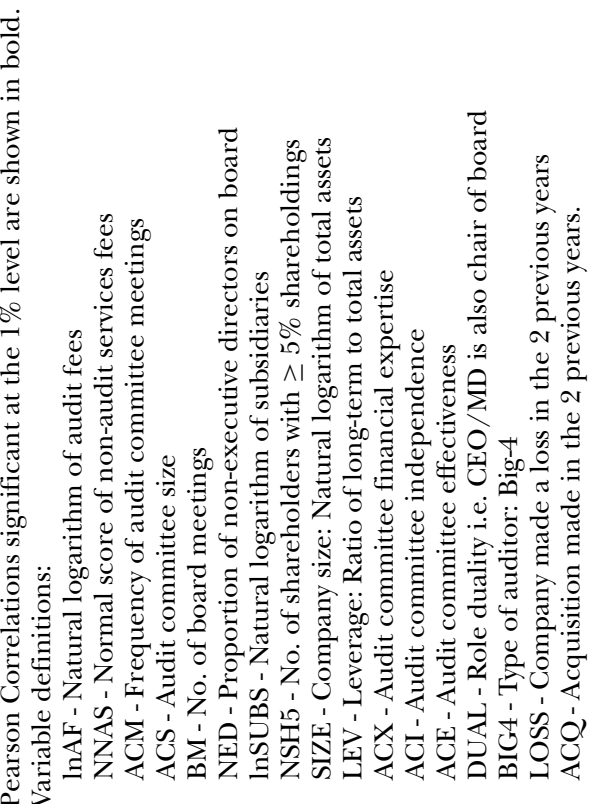
Table 4

$$
\begin{aligned}
& \text { OLS Regression of AF on ACE and Control Variables } \\
\ln \mathrm{AF}_{i t}= & \beta_{0}+\sum_{i=1}^{4} \delta_{i t x}(\mathrm{ACE})+\beta_{2} \mathrm{NED}_{i t}+\beta_{3} \mathrm{BM}_{i t}+\beta_{4} \mathrm{DUALITY}_{i t}+\beta_{5} \mathrm{BIG}_{i t} \\
& +\beta_{6} \mathrm{SIZE}_{i t}+\beta_{7} \ln \mathrm{SUBS}_{i t}+\beta_{8} \mathrm{LEV}_{i t}+\beta_{9} \mathrm{ACQ}_{i t}+\beta_{10} \mathrm{LOSS}_{i t} \\
& +\beta_{11} \mathrm{NSH} 5_{i t}+\sum_{i=1}^{5} \delta_{i t x}(\mathrm{INDY})+\beta_{12} \mathrm{~T}_{i t}
\end{aligned}
$$

\begin{tabular}{|c|c|c|c|c|c|c|}
\hline & $\begin{array}{l}\text { Predicted } \\
\text { Sign }\end{array}$ & $\begin{array}{c}\text { Model 1 } \\
(A C M=>3)\end{array}$ & Model 1a & $\begin{array}{c}\text { Model } 1 b \\
(A C M=>4)\end{array}$ & $\begin{array}{c}\text { Model 1c } \\
\text { (Big Clients) }\end{array}$ & $\begin{array}{c}\text { Model 1d } \\
\text { (Small Clients) }\end{array}$ \\
\hline$R^{2}$ & & 0.698 & 0.718 & 0.685 & 0.589 & 0.671 \\
\hline Adj. $R^{2}$ & & 0.687 & 0.707 & 0.674 & 0.559 & 0.649 \\
\hline Std. Error & & 0.440 & 0.435 & 0.460 & 0.434 & 0.435 \\
\hline$F$ value & & 66.528 & 62.600 & 62.577 & 19.903 & 30.107 \\
\hline & & $(p=0.00)$ & $(p=0.00)$ & $(p=0.00)$ & $(p=0.00)$ & $(p=0.00)$ \\
\hline Intercept & & $2.864^{* *}$ & $3.044^{* *}$ & $2.515^{* *}$ & $2.556^{*}$ & 0.202 \\
\hline $\operatorname{ACE}(\mathrm{H} 1)$ & + & $0.361^{* *}$ & & $0.221 * *$ & $0.387^{* *}$ & 0.110 \\
\hline ACI $\left(\mathrm{H}_{1 \mathrm{a}}\right)$ & + & & $0.897^{* *}$ & & & \\
\hline $\operatorname{ACX}\left(\mathrm{H}_{1 \mathrm{~b}}\right)$ & + & & 0.054 & & & \\
\hline $\operatorname{ACM}^{\mathrm{a}, \mathrm{b}}\left(\mathrm{H}_{1 \mathrm{c}}\right)$ & + & & $0.205^{* *}$ & & & \\
\hline $\operatorname{ACS}^{\mathrm{a}}\left(\mathrm{H}_{1 \mathrm{~d}}\right)$ & + & & $0.250^{* *}$ & & & \\
\hline $\mathrm{BM}^{\mathrm{b}}$ & + & $0.050 * *$ & $0.053^{* *}$ & $0.053^{* *}$ & $0.097 * *$ & 0.011 \\
\hline NED & + & -0.268 & $-0.438^{*}$ & -0.260 & -0.349 & -0.380 \\
\hline DUALITY & + & $-0.214^{*}$ & -0.062 & $-0.209^{*}$ & $-0.371^{* *}$ & -0.053 \\
\hline NSH5 & - & $-0.052^{* *}$ & $-0.059^{* *}$ & $-0.056^{* *}$ & $-0.067^{* *}$ & $-0.034^{*}$ \\
\hline SIZE & + & $0.432^{* *}$ & $\mathbf{0 . 3 8 3}{ }^{* *}$ & $0.453^{* *}$ & $0.422^{* *}$ & $0.572^{* *}$ \\
\hline LEVERAGE & + & $-0.305^{*}$ & -0.192 & $-0.323^{*}$ & $-0.463^{*}$ & -0.207 \\
\hline $\operatorname{lnSUBS}$ & + & $0.358^{* *}$ & $0.362^{* *}$ & $0.328^{* *}$ & $0.338^{* *}$ & $0.378^{* *}$ \\
\hline BIG4 & + & $0.389^{* *}$ & $0.207 * *$ & $0.405^{* *}$ & $0.448^{* *}$ & $0.501^{* *}$ \\
\hline ACQ & + & 0.078 & 0.062 & $0.115^{*}$ & 0.098 & 0.001 \\
\hline LOSS & + & 0.003 & -0.016 & -0.046 & -0.038 & 0.109 \\
\hline Industrials & $+/-$ & $-0.102^{*}$ & $-0.148^{* *}$ & $-0.143^{* *}$ & & \\
\hline Services & $+/-$ & & & & $0.137^{*}$ & $0.160^{*}$ \\
\hline Consumer goods & $+/-$ & -0.054 & $-0.287^{* *}$ & -0.168 & 0.159 & 0.008 \\
\hline Mineral extraction & $+/-$ & $0.514^{* *}$ & $0.541^{* *}$ & $0.505^{* *}$ & $1.021^{* *}$ & $0.364^{*}$ \\
\hline Utilities & $+/-$ & 0.090 & 0.039 & -0.013 & 0.082 & \\
\hline 2001 & $+/-$ & $-0.215^{* *}$ & $-0.204^{* *}$ & $-0.175^{* *}$ & -0.126 & \\
\hline 2002 & $+/-$ & $-0.120^{*}$ & $-0.112^{*}$ & -0.076 & -0.031 & 0.110 \\
\hline 2003 & $+/-$ & -0.088 & -0.071 & -0.045 & & 0.113 \\
\hline 2004 & $+/-$ & & & & 0.074 & $0.184^{*}$ \\
\hline
\end{tabular}

Notes:

$* *$ and $*$ indicates significant relationship at $1 \%(p<0.01)$ and at $5 \%(p<0.05)$ respectively.

See Table 3 for variable definitions.

${ }^{a}$ We re-run the regression for model la replacing the dichotomous data of ACS and ACM with the continuous format and the results remained the same except that the significance level for ACS dropped to $5 \%$.

${ }^{\mathrm{b}}$ We re-run the regression model for $1 \mathrm{a}$ by recoding ACM as 1 when the number of meetings was between 4 and 6 , and 0 otherwise as well as reclassifying $\mathrm{BM}$ into $<6,7-12$ and $>12$. We did not find any suggestions that our sample contained companies experiencing problems. The results were also confirmed by $\chi^{2}$ and correlation. 
LEV is only significant at the $5 \%$ level and in the direction opposite to prediction. Companies in the mineral extraction and industrial sectors seemed to pay the highest and lowest audit fees respectively compared to other counterparts. This supports the industry effect hypothesis. The results suggest that higher audit fees are associated with companies whose audit committees are effective, their companies' boards meet more regularly, have no role duality, are larger in size, have complex structure, audited by large audit firm, have less diffused ownership, lower gearing and belong to the mineral extraction sector.

Model 1a is the same as Model 1 but this time, the composite measure ACE was substituted with the independent variables related to the four dimensions of ACE. The results from this regression, reported in the fourth column of Table 4, show three of the four dimensions of ACE i.e., independence (ACI), diligence (ACM) and size (ACS) to be significantly related to audit fees in the direction as predicted at the $1 \%$ level. The dimension expertise (ACX) is not significantly related to audit fees. Thus, we found support for $\mathrm{H}_{1 \mathrm{a}}, \mathrm{H}_{1 \mathrm{c}}$ and $\mathrm{H}_{1 \mathrm{~d}}$ but not for $\mathrm{H}_{1 \mathrm{~b}}$. In other words, the recommendations by the Smith Report may be costly for companies as they would need to pay higher audit fees due to an extension in the scope of the audit to improve audit quality. Two board characteristics, i.e., number of board meetings (BM) and proportion of independent non-executive directors (NED) are significant at the $1 \%$ and $5 \%$ levels respectively, and in the direction opposite to prediction for NED. In the case of company-related control variables, the results are similar to those observed for Model 1 with the exception of DUALITY and LEV.

Model 1b is similar to Model 1 but this time we changed the dimension for ACM in the composite ACE measure from at least three meetings $(\geq 3)$ per year to at least four meetings $(\geq 4)$ per year, as recommended by other codes (e.g., Blue Ribbon Committee). We found the results - reported in the fifth column of Table 4 - to be the same as in the first model for both the independent variable of interest ACE (slightly lower coefficient than Model 1) and the two types of control variables.

Models $1 \mathrm{c}$ and $1 \mathrm{~d}$ are exactly the same as Model 1 but this time we ran the regressions separately for big clients (Model 1c) and small clients (Model 1d) based on the median of total assets as proxy for size. The results for Model 1c (big clients), reported under the sixth column of Table 4 , are the same as Model 1 , that is, a positive association between AF and ACE, as well as the other two types of control variables. However, we found no significant relationship between AF and ACE for small clients (Model 1d). The results also reveal that the two board effectiveness control variables found significant in Model 1c are not significantly related to AF in Model 1d (see seventh column of Table 4). A possible explanation for the results could be attributable to the lax attitude by the majority of small clients to strictly adhere to the effectiveness criteria to enhance audit quality by increasing scope of audit (hence, higher audit fees). The reason may be due to financial analysts paying less attention to the governance and audit quality of such companies. ${ }^{13}$ As for the company-related variables, the results in Model 1d are the same with Model 1c except for LEV, which is not significant for the small client sample.

13 Further analysis indicates that only four cases in our small client sample that pay high fees and adhere to the effectiveness criteria compared to 48 cases in our large client sample, and test of means indicate significant difference. On the contrary, 19 cases in our small client sample pay lower fees and adhere to the effectiveness criteria compared to 15 cases in our large client sample. This suggests that smaller clients are more concerned with the cost of the audit (fees) rather than effectiveness. 
Table 5

OLS Regression of NASF on ACE and Control Variables

$$
\begin{aligned}
\mathrm{NNASF}_{i t}= & \beta_{0}+\sum_{i=1}^{4} \delta_{i t x}(\mathrm{ACE})+\beta_{2} \mathrm{NED}_{i t}+\beta_{3} \mathrm{BM}_{i t}+\beta_{4} \mathrm{DUALITY}_{i t}+\beta_{5} \mathrm{BIG}_{i t} \\
& +\beta_{6} \mathrm{SIZE}_{i t}+\beta_{7} \ln \mathrm{SUBS}_{i t}+\beta_{8} \mathrm{LEV}_{i t}+\beta_{9} \mathrm{ACQ}_{i t}+\beta_{10} \mathrm{LOSS}_{i t} \\
& +\beta_{11} \mathrm{NSH}_{i t}+\sum_{i=1}^{5} \delta_{i t x}(\mathrm{INDY})+\beta_{12} \mathrm{~T}_{i t}+\varepsilon_{m 1}
\end{aligned}
$$

\begin{tabular}{|c|c|c|c|c|c|c|}
\hline & $\begin{array}{l}\text { Predicted } \\
\quad \text { Sign }\end{array}$ & $\begin{array}{c}\text { Model } 2 \\
(A C M=>3)\end{array}$ & Model $2 a$ & $\begin{array}{c}\text { Model } 2 b \\
(A C M=>4)\end{array}$ & $\begin{array}{c}\text { Model } 2 c \\
\text { (Big Clients) }\end{array}$ & $\begin{array}{c}\text { Model 2d } \\
\text { (Small Clients) }\end{array}$ \\
\hline$R^{2}$ & & 0.413 & 0.435 & 0.412 & 0.490 & 0.401 \\
\hline Adj. $R^{2}$ & & 0.391 & 0.411 & 0.391 & 0.451 & 0.358 \\
\hline Std. Error & & 0.770 & 0.757 & 0.771 & 0.711 & 0.711 \\
\hline$F$ value & & 19.164 & 18.040 & 19.140 & 12.600 & 9.311 \\
\hline & & $(p=0.00)$ & $(p=0.00)$ & $(p=0.00)$ & $(p=0.00)$ & $(p=0.00)$ \\
\hline Intercept & & $-7.435^{* *}$ & $-7.387^{* *}$ & $-7.787^{* *}$ & $-7.498^{* *}$ & $-7.091^{* *}$ \\
\hline $\operatorname{ACE}\left(\mathrm{H}_{2}\right)$ & - & $0.274^{* *}$ & & 0.118 & $0.451^{* *}$ & -0.178 \\
\hline ACI $\left(\mathrm{H}_{2 \mathrm{a}}\right)$ & - & & $-1.042^{* *}$ & & & \\
\hline $\operatorname{ACX}\left(\mathrm{H}_{2 \mathrm{~b}}\right)$ & - & & $-0.148^{*}$ & & & \\
\hline $\operatorname{ACM}^{\mathrm{a}, \mathrm{b}}\left(\mathrm{H}_{2 \mathrm{c}}\right)$ & - & & 0.022 & & & \\
\hline $\operatorname{ACS}^{\mathrm{a}}\left(\mathrm{H}_{2 \mathrm{~d}}\right)$ & - & & $0.221 * *$ & & & \\
\hline $\mathrm{BM}^{\mathrm{b}}$ & - & $0.053^{* *}$ & $0.054^{* *}$ & $0.055^{* *}$ & $0.109^{* *}$ & 0.021 \\
\hline NED & - & $1.188^{* *}$ & $0.835^{*}$ & $1.206^{* *}$ & 0.806 & $1.770 * *$ \\
\hline DUALITY & + & $0.348^{*}$ & 0.078 & $0.345^{*}$ & -0.110 & $0.965^{* *}$ \\
\hline NSH5 & - & $-0.035^{*}$ & -0.030 & $-0.037^{*}$ & $-0.057^{*}$ & -0.015 \\
\hline SIZE & + & $0.286^{* *}$ & $0.348^{* *}$ & $0.308^{* *}$ & $0.246^{*}$ & $0.286^{* *}$ \\
\hline LEVERAGE & + & 0.410 & 0.418 & 0.405 & -0.203 & $1.658^{* *}$ \\
\hline $\ln$ SUBS & + & 0.092 & 0.014 & 0.067 & 0.024 & 0.012 \\
\hline BIG4 & + & $0.914^{* *}$ & $1.170^{* *}$ & $0.930^{* *}$ & $1.489^{* *}$ & $0.882^{* *}$ \\
\hline $\mathrm{ACQ}$ & + & 0.037 & 0.086 & 0.063 & -0.044 & 0.214 \\
\hline LOSS & + & 0.142 & $0.154^{*}$ & 0.109 & $0.402 * *$ & $-0.269^{*}$ \\
\hline Industrials & $+/-$ & 0.037 & 0.019 & 0.006 & & \\
\hline Services & $+/-$ & & & & 0.200 & $-0.215^{*}$ \\
\hline Consumer goods & $+/-$ & 0.282 & $0.461^{* *}$ & 0.207 & $0.619 *$ & $-0.575^{* *}$ \\
\hline Mineral extraction & $+/-$ & $-0.871^{* *}$ & $-0.720^{* *}$ & $-0.882^{* *}$ & 0.085 & $-1.311^{* *}$ \\
\hline Utilities & $+/-$ & $-1.022^{*}$ & $-1.134^{* *}$ & $-1.081^{* *}$ & $-0.983^{* *}$ & \\
\hline 2001 & $+/-$ & 0.141 & 0.019 & 0.158 & $0.362^{* *}$ & \\
\hline 2002 & $+/-$ & 0.017 & -0.046 & 0.040 & $0.301^{*}$ & -0.210 \\
\hline 2003 & $+/-$ & -0.070 & -0.073 & -0.043 & & -0.023 \\
\hline 2004 & $+/-$ & & & & $0.269^{*}$ & -0.058 \\
\hline Std.Residual & $+/-$ & $0.268^{* *}$ & $0.295^{* *}$ & $0.280^{* *}$ & $0.220^{* *}$ & $0.267 * *$ \\
\hline
\end{tabular}

Notes:

$* *$ and $*$ indicates significant relationship at $1 \%(p<0.01)$ and at $5 \%(p<0.05)$ respectively.

See Table 3 for Variable definitions.

${ }^{a}$ We re-run the regression for model 2 a after replacing the dichotomous data of ACS and ACM with the continuous format and the results remained the same except that the significance level for ACI dropped to $5 \%$.

${ }^{\mathrm{b}}$ We re-run the regression model for $2 \mathrm{a}$ by recoding ACM as 1 when the number of meetings was between 4 and 6 and zero otherwise as well as reclassifying BM into $<6,7-12$ and $>12$. We did not find any suggestions that our sample contained companies experiencing problems. The results were also confirmed by $\chi^{2}$ and correlation.

Table 5 presents the results from the regression of normalised non-audit services fees (NNASF) on the composite measure of audit effectiveness (ACE), the variables related to the four dimensions of ACE [independence (ACI), expertise (ACX), diligence $(\mathrm{ACM})$, and size (ACS) ], board effectiveness control variables (BM, NED and DUAL- 
ITY), and company-related control variables. We ran the model five times, referred to as Model 2, 2a, 2b, 2c and 2d. The $F$-value for each model is significant at the $1 \%$ level and the adjusted $R^{2}$ for each of the five models ranges between $36 \%$ and $45 \%$.

Model 2 examines the association between NASF and the composite measure of ACE, board effectiveness and company-related control variables, including the year and residuals of $\operatorname{lnAF}$. The results from Model 2 - reported in the third column of Table 5 - indicate that NNASF is significantly related to ACE (at the 1\% level) but this is opposite to the predicted direction. Thus, the results do not support our second hypothesis $\left(\mathrm{H}_{2}\right)$. The results imply that companies incur high NASF when audit committees are comprised of all independent non-executive directors, have at least one member with financial expertise, meet at least three times a year and have at least three members. We also find all three board effectiveness variables to be significant; BM and NED at the $1 \%$ significance level but in the direction opposite to prediction while DUALITY at the $5 \%$ significance level in the direction as predicted. Three company-related control variables are significantly related to NASF; SIZE, BIG4 and residuals are significant at the $1 \%$ level and NSH5 at the $5 \%$ level, in the direction as predicted. Companies in the mineral extraction and utilities sectors pay the lowest NASF compared to their counterparts. In short, results of Model 2 suggest that higher NASF are associated with companies whose audit committees are effective, their boards meet more regularly, the boards are comprised of majority non-executive directors, they are companies with role duality, have less diffused ownership, are larger in size, and are audited by large audit firms.

Model $2 \mathrm{a}$ is the same as Model 2 but this time we substitute ACE with the independent variables related to the four dimensions of ACE. The results from this regression, reported in the fourth column of Table 5, show three of the four dimensions of ACE i.e., independence (ACI), expertise (ACX) and size (ACS) to be significantly related to NASF in the direction as predicted at the $1 \%$ level for ACI and at the $5 \%$ level for ACX. But it is in the direction opposite to prediction for ACS at the $1 \%$ significance level. The dimension diligence (ACM) is not significantly related to NASF. Thus, we found support for $\mathrm{H}_{2 \mathrm{a}}$ and $\mathrm{H}_{2 \mathrm{~b}}$ but not for $\mathrm{H}_{2 \mathrm{c}}$. Although $\mathrm{H}_{2 \mathrm{~d}}$ is found to be significant, it is in the direction opposite to prediction and therefore $\mathrm{H}_{2 \mathrm{~d}}$ is not supported. Results for the board effectiveness are similar to those observed for Model 2 with the exception of DUALITY which is not significant in the case of Model 2a. As for the company-related control variables, results are similar to Model 2 except that the variable shareholders (NSH5) is no longer significant in Model 2a, while LOSS which is insignificant in Model 2 - is significant in Model 2a.

Model $2 \mathrm{~b}$ is similar to Model 2 but the dimension for ACM in the composite ACE measure was replaced with at least four meetings $(\geq 4)$ per year instead of three meetings. We find the results on the relationship between NASF and ACE, reported in the fifth column of Table 5, to be no longer significant. This suggests that the more frequent the audit committee meets ( $\geq 4$ compared to $\geq 3$ in Model 2), the lesser the impact on NASF. In other words, the frequency of meetings is not the main driver for level of NASF. As in Model 2, the results for the two types of control variables are the same.

Models 2c and 2d are exactly the same as Model 2 but this time we ran the regressions separately for big clients (Model 2c) and small clients (Model 2d), based on the median of total assets as a proxy for size. The results for Model 2c (big clients), reported in the sixth column of Table 5, are the same as in Model 2 i.e., positive 
association between NASF and ACE as well as the company-related control variables. However, two of the board effectiveness control variables, NED and DUALITY, are insignificant. This suggests that larger clients are more likely to buy NAS even with effective audit committees perhaps due to complexity in their activities. In the case of small clients (Model 2d), we find an insignificant relationship between NASFand ACE and the direction of the relationship is negative. This means that for smaller clients, an effective audit committee is not associated with NASF. ${ }^{14}$ The results also reveal that the two board effectiveness control variables found not significant in Model 2c are significantly related to NASF in Model $2 \mathrm{~d}$ (see seventh column of Table 5). As for the company-related control variables, the results in Model $2 \mathrm{~d}$ indicate that SIZE, LEV and BIG4 are significantly related at the $1 \%$ level to NASF in the direction as predicted. The variable LOSS is significantly related to NASF at the $5 \%$ level but in the direction opposite to that predicted.

\section{(iii) Further Analysis}

In order to ensure that our results are rigorous, we conducted several further tests. Since our data shows cases where the amount of NAS exceeds the amount of audit fees, we also ran logistic regressions for Model $2 \mathrm{a}$ for both the pooled data and yearly data with NAS being a dichotomous variable i.e., 1 if the amount of purchased NAS is greater than audit fees, and 0 otherwise. Table 6 presents the results.

Results based on pooled data indicate that companies paying higher NASF compared to AF are those with larger audit committees, more independent boards, audited by BIG4 and mainly belonging to the industrials and consumer goods sectors while those paying less NASF compared to AF are those with less independent audit committees and less number of subsidiaries (complexity). The yearly analysis suggests that in 2001, higher payment of NASF is associated with board independence, while lower NASF is associated with substantial shareholdings. In 2002, higher NASF is associated with companies that are bigger, underperforming and have acquisitions, while lower NASF are associated with companies with less board meetings and less number of subsidiaries (less complexity). In 2003, the higher NASF is associated with companies in the industrial sector and those having substantial shareholdings. Finally, for 2004, higher NASF is associated with larger audit committees, more independent boards and companies belonging to the industrials and consumer goods sectors while those paying lower NASF are those with fewer acquisitions.

We ran Models 1a and 2a by year to explore if the relationships noted change across the years. Additionally, we ran the models by dropping all the non-BIG4 clients to ensure that the inclusion of these companies will not skew the results. Tables 7 and 8 present the results.

It can be seen from Table 7 that for 2002, the three components of ACE are all significantly related to AF with the exception of ACX, a result similar to the pooled data. For 2003, two variables, ACS and ACI are significantly associated with AF. In the case of 2001 and 2004, only ACS and ACI are significantly associated with $\mathrm{AF}$, respectively. When we drop the companies audited by non-BIG4 from the model, we find the results do remain the same, i.e., the three components of ACE

14 The insignificant result is due to no significant difference for small clients with ACE that pay high NASF (7 cases) and low NASF (16 cases). 
Table 6

Logistic Regression with Dependent Variable when NASF is Greater Than AF

\begin{tabular}{|c|c|c|c|c|c|}
\hline Dependent Variable: NASF $>$ AF & $\begin{array}{c}A l l \\
B\end{array}$ & $\begin{array}{c}2001 \\
\boldsymbol{B}\end{array}$ & $\begin{array}{c}2002 \\
\boldsymbol{B}\end{array}$ & $\begin{array}{c}2003 \\
\boldsymbol{B}\end{array}$ & $\begin{array}{c}2004 \\
\boldsymbol{B}\end{array}$ \\
\hline \multicolumn{6}{|l|}{ ACE components: } \\
\hline ACI & $-3.39^{* *}$ & -36.08 & -47.59 & -60.86 & 19.25 \\
\hline ACX & 0.07 & 0.06 & 0.44 & -0.02 & -0.89 \\
\hline ACM & -0.28 & -1.13 & 0.12 & 0.03 & -0.97 \\
\hline ACS & $0.81^{* *}$ & 0.79 & -0.31 & 0.11 & $1.60^{*}$ \\
\hline BM & 0.07 & 0.22 & $-0.38^{*}$ & -0.01 & 0.13 \\
\hline NED & $3.32^{* *}$ & $5.88^{*}$ & 1.00 & 1.35 & $12.18^{* *}$ \\
\hline DUALITY & -0.24 & -53.64 & -0.43 & 18.85 & 22.85 \\
\hline NSH5 & 0.02 & $-0.40^{*}$ & 0.08 & $0.37^{*}$ & 0.14 \\
\hline $\operatorname{lnTA}$ & 0.14 & -0.08 & $2.12^{* *}$ & -0.72 & 0.70 \\
\hline LEVERAGE & -0.48 & -2.65 & -1.63 & 4.24 & -0.93 \\
\hline $\operatorname{lnSUB}$ & $-0.29^{*}$ & 0.04 & $-1.67^{* *}$ & -0.49 & -0.29 \\
\hline BIG4 & $1.86^{* *}$ & 17.40 & 20.02 & 56.32 & 1.08 \\
\hline ACQ & 0.02 & -0.20 & $1.58^{*}$ & 0.58 & $-1.71^{*}$ \\
\hline LOSS & 0.23 & -0.29 & $1.82^{*}$ & 1.01 & -0.20 \\
\hline Industrials & $0.69 * *$ & -0.07 & 0.73 & $1.59^{*}$ & $1.28^{*}$ \\
\hline Consumer goods & $2.28^{* *}$ & 33.05 & 1.71 & 20.98 & $3.90^{* *}$ \\
\hline Mineral extraction & -19.65 & -19.95 & -18.29 & -18.63 & -19.29 \\
\hline Utilities & -21.57 & -21.69 & -22.26 & -22.03 & -21.90 \\
\hline Constant & -4.05 & 17.20 & -8.32 & 13.65 & -41.10 \\
\hline No. of NASF $>$ AF [1] & 211 & 58 & 52 & 51 & 50 \\
\hline No. of AF $>$ NASF [0] & 329 & 77 & 83 & 84 & 85 \\
\hline Nagelkerke $R$ Square & 0.271 & 0.572 & 0.595 & 0.53 & 0.52 \\
\hline
\end{tabular}

Notes:

$* *$ and ${ }^{*}$ indicates significant relationship at $1 \%(p<0.01)$ and at $5 \%(p<0.05)$ respectively.

See Table 3 for Variable definitions.

are all significantly related to AF with the exception of ACX, a result similar to the pooled data. This suggests that for companies audited by BIG4, AF are associated with audit committee size, frequency of audit committee meetings and audit committee independence.

Results in Table 8 show independence (ACI), expertise (ACX) and size (ACS) to be significantly related to NASF at the $1 \%$ and $5 \%$ level in the direction as predicted but ACS is significantly related to NASF at the $1 \%$ level but in the direction opposite to the prediction. Looking at the yearly basis, ACI is significantly related to NASF for each year except for 2004. ACX and ACS are significantly related to NASF at the $1 \%$ and $5 \%$ levels, respectively only for 2004 . When we drop the companies audited by nonBIG4 from the model, the results show no significant relationship between NASF and audit committee effectiveness variables. This indicates that for companies audited by big audit firms, NASF are not associated with any of the audit committee effectiveness components as defined in the context of our study.

\section{SUMMARY AND CONCLUSIONS}

This paper examines the possible influence of corporate governance quality, especially audit committee effectiveness, on auditor remuneration. Audit committees not only 
Table 7

OLS Regression for Audit Fees (AF) (on yearly basis and based on big audit firm)

\begin{tabular}{|c|c|c|c|c|c|c|}
\hline & $\begin{array}{c}\text { All } \\
\text { (excl.year) }\end{array}$ & 2001 & 2002 & 2003 & 2004 & $\begin{array}{l}\text { Big Audit } \\
\text { Firms Only }\end{array}$ \\
\hline (Constant) & $2.806^{* *}$ & $2.288^{* *}$ & $2.833^{* *}$ & 1.331 & $4.014^{* *}$ & $3.144^{* *}$ \\
\hline \multicolumn{7}{|l|}{ ACE components } \\
\hline ACI & $0.952^{* *}$ & $0.913^{* *}$ & $0.603^{*}$ & $1.657^{* *}$ & 0.735 & $0.807^{*}$ \\
\hline ACX & 0.079 & 0.035 & 0.150 & 0.100 & 0.024 & 0.057 \\
\hline ACM & $0.253^{* *}$ & 0.202 & $0.417^{* *}$ & 0.148 & 0.139 & $0.287^{* *}$ \\
\hline ACS & $0.211^{* *}$ & -0.078 & $0.236^{*}$ & 0.406 ** & $0.334^{* *}$ & $0.211^{* *}$ \\
\hline $\mathrm{BM}$ & $0.055^{* *}$ & $0.047^{* *}$ & $0.041^{*}$ & $0.078^{* *}$ & 0.024 & $0.064^{* *}$ \\
\hline NED & -0.366 & 0.349 & $-1.013^{*}$ & -0.272 & -0.681 & -0.146 \\
\hline DUALITY & 0.058 & 0.066 & 0.036 & 0.061 & -0.040 & 0.004 \\
\hline NSH5 & $-0.057^{* *}$ & $-0.090^{* *}$ & $-0.048^{*}$ & $-0.075^{* *}$ & $-0.052^{*}$ & $-0.049^{* *}$ \\
\hline SIZE & $0.384^{* *}$ & $0.394^{* *}$ & $0.422^{* *}$ & $0.435^{* *}$ & $0.348^{* *}$ & $0.369^{* *}$ \\
\hline LEVERAGE & -0.225 & $-0.908^{* *}$ & -0.456 & -0.526 & 0.124 & -0.095 \\
\hline $\ln S$ & 0.31 & $0.495^{* *}$ & $0.299^{* *}$ & $0.409^{* *}$ & $2 * *$ & $0.375^{* *}$ \\
\hline BIG4 & $0.185^{*}$ & 0.39 & 0.250 & -0.093 & $0.359^{*}$ & \\
\hline ACQ & 0.054 & 0.059 & 0.168 & -0.175 & 0.159 & 0.071 \\
\hline LOSS & -0.023 & -0.058 & -0.084 & -0.110 & 0.130 & 0.019 \\
\hline Industrials & $-0.145^{* *}$ & $-0.298^{* *}$ & -0.101 & -0.161 & -0.095 & $-0.188^{* *}$ \\
\hline Consumer goods & $-0.305^{* *}$ & -0.356 & -0.183 & $-0.415^{*}$ & -0.165 & $-0.401^{* *}$ \\
\hline Mineral extraction & $0.523^{* *}$ & 0.265 & 0.572 & 0.171 & $0.757^{*}$ & $0.574^{* *}$ \\
\hline Utilities & -0.052 & 0.181 & -0.490 & -0.004 & 0.335 & -0.159 \\
\hline $\boldsymbol{R}^{2}$ & 0.711 & 0.821 & 0.742 & 0.731 & 0.676 & 0.703 \\
\hline Adj & 0.701 & 0.793 & 0.703 & 0.69 & 0.626 & 0.692 \\
\hline Std & 0.440 & 0.375 & 0.450 & 0.446 & 0.457 & 0.442 \\
\hline$F$ value & $\begin{array}{l}71.0 \\
(p=0.00)\end{array}$ & $\begin{array}{l}29.1 \\
(b=0.00)\end{array}$ & $\begin{array}{l}18.6 \\
(b=0.00\end{array}$ & $\begin{array}{c}17.5 \\
(b=0\end{array}$ & 13.5 & 64.5 \\
\hline
\end{tabular}

Notes:

** and * indicates significant relationship at $1 \%(p<0.01)$ and at $5 \%(p<0.05)$ respectively.

See Table 3 for Variable definitions.

play an important monitoring role to assure the quality of financial reporting and corporate accountability (Carcello and Neal, 2000), but they also serve as an important governance mechanism. The potential litigation risk and reputation impairment faced by audit committee members incentivises them to discharge their responsibilities effectively. Thus, we expect that firms with high-quality audit committees are more likely to monitor the external audit process than firms with low-quality audit committees. Hence, we can expect audit fees to increase due to wider scope of audit to ensure audit quality. We further expect firms with high-quality audit committees to enhance auditor independence and this would be reflected in lower NASF. We explore these two propositions in this paper.

The results provide evidence of audit committee effectiveness (ACE) having a positive significant effect on $\mathrm{AF}$ after controlling for board of director characteristics, implying that in ensuring higher audit quality, the scope of the audit, and in turn, audit fees, will be increased. Our findings are consistent with the US study of Abbott and Parker (2000) who note that active audit committees are more diligent and therefore require higher audit quality in order to protect themselves from financial and reputational loss. It is noteworthy that we provide evidence that ACE has a significant positive effect on AF after controlling for board characteristics. This is in 


\section{Table 8}

OLS Regression for Non-Audit-Services Fees (NASF) (on yearly basis and based on big audit firm)

\begin{tabular}{|c|c|c|c|c|c|c|}
\hline NNASF Model $2 a$ & $\begin{array}{c}\text { All } \\
\text { (excl.year) }\end{array}$ & 2001 & 2002 & 2003 & 2004 & $\begin{array}{l}\text { Big Audit } \\
\text { Firms Only }\end{array}$ \\
\hline (Constant) & $-7.377 * *$ & $-8.704^{* *}$ & $-11.387^{* *}$ & -2.037 & $-9.949 * *$ & $-8.502^{* *}$ \\
\hline \multicolumn{7}{|l|}{ ACE components } \\
\hline ACI & $-1.068^{* *}$ & $-1.147^{*}$ & $-2.773^{* *}$ & $-1.953^{*}$ & 0.503 & 0.211 \\
\hline ACX & $-0.154^{*}$ & 0.208 & 0.003 & -0.262 & $-\mathbf{0 . 6 8 3}^{* *}$ & -0.075 \\
\hline ACM & 0.024 & -0.190 & -0.020 & 0.018 & 0.019 & -0.052 \\
\hline ACS & $0.223^{* *}$ & 0.094 & 0.022 & -0.012 & $0.404^{*}$ & 0.161 \\
\hline $\mathrm{BM}$ & $0.054^{* *}$ & $0.114^{* *}$ & 0.009 & 0.041 & -0.004 & $0.031^{*}$ \\
\hline NED & $0.823^{*}$ & 0.483 & -0.256 & 0.175 & $3.141^{* *}$ & 0.603 \\
\hline DUALITY & 0.064 & $-1.061^{* *}$ & 0.160 & -0.077 & $1.658^{* *}$ & 0.171 \\
\hline NSH5 & $-0.029^{*}$ & $-0.184^{* *}$ & -0.005 & 0.027 & 0.020 & -0.029 \\
\hline SIZE & $0.348^{* *}$ & $0.448^{* *}$ & $\mathbf{0 . 6 7 0}^{* *}$ & 0.090 & $0.406^{* *}$ & $0.428^{* *}$ \\
\hline LEVERAGE & 0.437 & -0.455 & -0.128 & $1.841^{*}$ & 0.734 & 0.160 \\
\hline $\operatorname{lnSUBS}$ & 0.015 & 0.209 & $-0.173 *$ & -0.010 & -0.032 & -0.037 \\
\hline BIG4 & $1.173^{* *}$ & $1.409^{* *}$ & $2.025^{* *}$ & $1.463^{* *}$ & $0.696 * *$ & - \\
\hline $\mathrm{ACQ}$ & 0.083 & $-0.460 *$ & 0.261 & 0.290 & -0.272 & 0.069 \\
\hline LOSS & $0.151^{*}$ & -0.006 & $0.368^{* *}$ & 0.297 & -0.137 & 0.091 \\
\hline Industrials & 0.019 & $-0.396^{*}$ & 0.049 & 0.074 & 0.111 & 0.071 \\
\hline Consumer goods & $0.464^{* *}$ & 0.593 & 0.313 & $0.731 *$ & 0.386 & $0.502^{* *}$ \\
\hline Mineral extraction & $-0.716^{* *}$ & $-1.373^{* *}$ & -0.306 & $-1.330^{*}$ & -0.360 & $-0.858^{* *}$ \\
\hline Utilities & $-1.144^{* *}$ & -1.015 & -0.436 & -1.276 & $-1.865^{* *}$ & $-1.003^{* *}$ \\
\hline Std. Residua & $0.296 * *$ & $0.296 * *$ & $0.359 * *$ & $0.369^{* *}$ & $0.228^{* *}$ & $0.328^{* *}$ \\
\hline$R^{2}$ & 0.434 & 0.647 & 0.673 & 0.440 & 0.517 & 0.391 \\
\hline Adj. $R^{2}$ & 0.413 & 0.588 & 0.619 & 0.348 & 0.438 & 0.368 \\
\hline Std. Error & 0.760 & 0.684 & 0.606 & 0.797 & 0.683 & 0.750 \\
\hline$F$ value & $\begin{array}{l}20.8 \\
(p=0.00)\end{array}$ & $\begin{array}{l}10.1 \\
(p=0.00)\end{array}$ & $\begin{array}{l}12.4 \\
(p=0.00)\end{array}$ & $\begin{array}{c}4.7 \\
(p=0.00)\end{array}$ & $\begin{array}{c}6.5 \\
(p=0.00)\end{array}$ & $\begin{array}{l}16.5 \\
(p=0.00)\end{array}$ \\
\hline
\end{tabular}

Notes:

** and ${ }^{*}$ indicates significant relationship at $1 \%(p<0.01)$ and at $5 \%(p<0.05)$ respectively. See Table 3 for Variable definitions.

contrast to the US study of Carcello et al. (2002) and Goodwin-Stewart and Kent (2006) for Australia, who conclude that audit committee variables provide no incremental explanatory power when board variables are included in the audit fee model. It is possible that the Carcello et al. (2002) findings are insignificant with respect to audit committees because their data relates to 1992 when audit committees may not have had relatively significant oversight responsibility for financial reporting and audit. Furthermore, their study only considered big clients while the current study considered both. However, consistent with Carcello et al. (2002), the variable for frequency of board meetings in our model has a significant positive association with audit fees. The insignificant finding by Goodwin-Stewart and Kent (2006) could be attributed to their lower incidence of ACX and ACM (only 29\% and two meetings on average respectively) within a large sample size. We also find that $\ln$ TA (company size), lnSUBS (number of subsidiaries), and auditor type (BIG4), all have a significant positive association with AF. Consistent with Firth's (1997) findings, NSH5 (number of shareholders owning $5 \%$ or more shares) has a significant negative association with AF which may suggest that large shareholders may use different methods to 
monitor managerial actions instead of heavily relying on the audit; hence, diffused shareholding companies rely more on external audit function. The findings in Parkash and Venable (1993) and Firth (1997) - where audit fees are seen to increase with higher leverage - appear to be contradicted by the negative relationship of leverage in this study. This result provides an area for further investigation as many studies on audit fees have found leverage to be positively associated with audit fees (Hay et al., 2006b).

Our paper also provides evidence that audit committee effectiveness (ACE) has a significant positive association with levels of NASF, which is contrary to our expectation. The results may imply that such audit committees are less concerned about protecting (perceived) auditor independence and, thus, do not restrain companies from purchasing NAS from the incumbent auditors. Furthermore, we find that NASF is negatively associated with audit committee financial expertise (ACX) and audit committee independence (ACI), indicating that such characteristics decrease the purchase of NAS. However, audit committee size (ACS) is positively related to NASF, implying that larger size audit committees do not stop companies from buying NAS. Contrary to our expectations, audit committee meetings (ACM) has a positive, but not significant, association with NASF. Additionally, our results show that number of board meetings (BM), role duality (DUALITY), board independence (NED), company size (lnTA) and big-four auditor (BIG4) have a positive significant association with level of NASF whereas shareholdings (NSH5) has a negative significant association with NASF.

\section{Limitations of the Study and Avenues for Further Research}

Our paper is, of course, not without limitations. Firstly, we use only four factors in our composite measure of audit committee effectiveness based on the recommendations of the Smith Report (2003). Further research is needed to better understand the factors which contribute to audit committee effectiveness in different regulatory and institutional contexts.

Secondly, we use a dichotomous measure of financial expertise, coded 1 if at least one member in the audit committee has financial expertise, and 0 otherwise. Future research could use a measure based on proportion i.e., number of members in the audit committees having financial expertise divided by the total number of audit committee members, and also control for board expertise. In order to use such measures, it is important that companies disclose clearly the credentials of their audit committee and board members (Zhang et al., 2007).

Closely related to the above, our third limitation is that our definition of financial expertise is perhaps too broad and encompasses skills that may not necessarily contribute to audit committee effectiveness. Hence, future studies may decompose the current definition of financial expertise into more specific types of financial expertise e.g., accounting, finance, tax, and then investigate their association with AF and NASF (see Krishnan and Visvanathan, 2009). Again, this is dependent on companies' public disclosures of such information.

Finally, while we document an association between corporate governance characteristics and auditor remuneration, our research does not provide evidence of causation nor examine the precise mechanism by which audit committees influence audit fees. Future research might investigate the complementary roles of boards and audit committees in monitoring both audit and financial reporting quality. In the 
UK the influence of effective audit committees on financial reporting has not been investigated, especially post-Enron.

\section{APPENDIX}

\begin{tabular}{lcc}
\hline US & UK & Australia \\
\hline Share Ownership & Share Ownership & Share Ownership \\
$\bullet$ 34\% individuals owning & $\bullet 22 \%$ individuals owning & $\bullet 37 \%$ individuals owning \\
shares in 2002. & shares in 2002. & shares in 2002. \\
$\begin{array}{c}\text { Accounting profession } \\
\text { (AICPA): }\end{array}$ & Accounting profession & Accounting profession (ICAA \\
(ICAEW, ICAS, ICAI, & \& CPA):
\end{tabular}

Size: 335,110

Practising: 128,700

\section{ACCA):}

Size: 252,690

Practising: 62,380

Students: 191,600

Frequency of Reporting

Listed companies required to produce quarterly reports

\section{Compliance}

Rule-based approach but SEC in 2003 called its vision the 'objectives-oriented approach.'

\section{Corporate Governance:} Sarbanes-Oxley Act 2002

- The audit firm must identify public audit clients, all accountants associated with those clients, list fees earned for audit and non-audit services, explain its audit quality procedures and identify all legal proceedings against the firm in connection with an audit.

- All audit committees in companies must consist of independent directors (see Section 3.3.3 \& 11.4.3.1).

- Audit firms are appointed by, and report to, the audit committee.

- Auditors are prohibited in undertaking consultancy work except for tax services but must be approved by the company's audit committee.

- Requires five-year rotation of the audit partner.

\section{Frequency of Reporting}

Listed companies required to produce half-yearly reports.

\section{Compliance}

Voluntary approach of 'comply or explain'

\section{Corporate Governance:}

Combined Code under the responsibility of the Financial Reporting Council (FRC) including Turnbull Report (1999), Smith Report (2003) \& Higgs Report (2003).
Size: 40,650

Practising: 16,260

Students: 10,950

Frequency of Reporting

\section{Compliance}

Voluntary approach of 'comply or explain'

\section{Corporate Governance:}

Principles of Good Corporate Governance and Best Practice Recommendations by the ASX Corporate Governance Council (2002). 


\section{APPENDIX (Continued)}

\section{Audit Committees: Blue Ribbon Committee on Improving Effectiveness of Corporate Audits (1999)}

- Listed companies must have an audit committee with at least three directors being independent and financially literate.

- Audit committee must approve non-audit services provided by the firm.

\section{Audit Committees: Smith} Report (2003)

-3.1. Audit committees should include at least three members, who should all be independent non-executive directors

- 3.2. The chairman of the company should not be an audit committee member.

-3.4 Appointments should be for a period of up to three years, extendable by no more than two additional three-year periods, so long as members continue to be independent.

- 3.5 recommended there should be no fewer than three meetings during the year, held to coincide with key dates within the financial reporting and audit cycle

-3.16. At least one member of the audit committee should have significant, recent and relevant financial experience, for example as an auditor or a finance director of a listed company. It is highly desirable for this member to have a professional qualification from one of the professional accountancy bodies.

-3.17. The company should provide an induction programme for new audit committee members.
Audit Committees: ASX CGC (2003) Principle 4.3

- AC should be structured so that it consists of only non-executive directors, a majority of which are independent directors,

- AC must have an independent chairperson, who is not chairperson of the Board

- AC should have at least 3 members

Source: Roberts et al. (2005).

\section{REFERENCES}

Abbott, L.J. and S. Parker (2000), 'Auditor Selection and Audit Committee Characteristics', Auditing: A Journal of Practice and Theory, Vol. 19, No. 2, pp. 47-66.

, G.F. Peters and K. Raghunandan (2003), 'An Empirical Investigation of Audit Fees, Non-Audit Fees, and Audit Committees', Contemporary Accounting Research, Vol. 20, No. 2, pp. 215-34.

Archambeault, D. and T. DeZoort (2001), 'Auditor Opinion Shopping and the Audit Committee', International Journal of Auditing, Vol. 5, No. 1, pp. 33-52. 
Ashbaugh, H., R. LaFond and B. W. Mayhew (2003), 'Do Non-audit Services Compromise Auditor Independence?', The Accounting Review, Vol. 78, No. 3, pp. 611-39.

Barkess, L. and R. Simnett (1994), 'The Provision of Other Services by Auditors: Independence and Pricing Issues', Accounting and Business Research (Spring), pp. 99-108.

Beasley, M. (1996), 'An Empirical Analysis of the Relation Betweenthe Board of Director Composition and Financial Statement Fraud,' The Accounting Review, Vol. 71, No. 4, pp. 443-65.

_ J. Carcello, D. Hermansonand and P. Lapides (2000), 'Fraudulent Financial Reporting: Consideration of Industry Traits and Corporate Governance Mechanisms,' Accounting Horizons, Vol. 14, pp. 441-54.

rary Accounting Research, Vol. 26, No. 1, pp. 65-122.

Beattie, V., S. Fearnley and R. Brandt (1999), 'Perceptions of Auditor Independence: UK Evidence', Journal of International Accounting, Auditing and Taxation, Vol. 8, No. 1, pp. 67-107.

Bedard, J. and S. M. Paquette (2008), Audit Committee Expertise, Auditor Provision of Tax Services, and Independence Risk, SSRN Working Paper (Available at SSRN: http://ssrn.com/abstract=1084099).

Beekes, W. and P. Brown (2006), 'Do Better Governed Australian Firms Make More Informative Disclosures?', Journal of Business Finance $\mathcal{E}$ Accounting, Vol. 33, Nos. 3 \& 4, pp. 422-50.

Blue Ribbon Committee on Improving the Effectiveness of Corporate Audit Committees (1999). Report and Recommendations of the Blue Ribbon Committee on Improving the Effectiveness of Corporate Audit Committees (New York: New York Stock Exchange and the National Association of Securities Dealers).

Byard, D., Y. Li and J. Weintrop (2006), 'Corporate Governance and the Quality of Financial Analysts Information,' Journal of Accounting and Public Policy, Vol. 25, No. 5, pp. 609-25.

Cadbury Report (1992), Financial Aspects of Corporate Governance (London: Gee).

Carcello, J. and T. Neal (2000), 'Audit Committee Composition and Auditor Reporting', The Accounting Review, Vol. 75, No. 4 (October), pp. 453-67.

,D. Hermanson, T. Neal and R. Riley Jr. (2002), 'Board Characteristics and Audit Fees', Contemporary Accounting Research, Vol. 9, No. 3 (Fall), pp. 365-84.

- C. Hollingsworth, A. Klein and T. Neal (2006), 'Audit Committee Financial Expertise, Competing Corporate Governance Mechanisms, and Earnings Management', Working Paper (February), (http://papers.ssrn.com/sol3/papers.cfm?abstract_id= 887512\&rec $=1 \&$ srcabs $=10569)$.

Clatworthy, M. and M. Peel (2007), 'The Effect of Corporate Status on External Audit Fees: Evidence From the UK', Journal of Business Finance $\mathcal{E}$ Accounting, Vol. 34, Nos. 1-2, pp. 169-201.

Cohen, J., G. Krishnamoorthy and A. Wright (2004), 'The Corporate Governance Mosaic and Financial Reporting Quality', Journal of Accounting Literature, Vol. 23, pp. 87-148.

Collett, P. and S. Hrasky (2005), 'Voluntary Disclosure of Corporate Governance Practices by Listed Australian Companies', Corporate Governance: An International Review, Vol. 13, No. 2 (March), pp. 188-96.

Collier, P. and A. Gregory (1996), 'Audit Committee Effectiveness and the Audit Fee', The European Accounting Review, Vol. 5, Issue 2, pp. 177-98.

_ and M. Zaman (2005), 'Convergence in European Corporate Governance: The Audit Committee Concept', Corporate Governance: An International Review, Vol. 13, No. 6, pp. 753-68.

Conyon, M. (2000), 'Discussion of the Increasing Use of Non-Executive Directors: Its Impact on UK Board Structure and Governance Arrangements', Journal of Business Finance $\mathcal{F}^{\circ}$ Accounting, Vol. 27, No. 9, pp. 1343-48.

Davidson, W., N. Xie and W. Xu (2004), 'Market Reaction to Voluntary Announcements of Audit Committee Appointments: The Effect of Financial Expertise', Journal of Accounting and Public Policy, Vol. 23, pp. 279-93.

DeFond, M., R.H. Hann and X. Hu (2005), 'Does the Market Value Financial Expertise on Audit Committees of Boards of Directors', Journal of Accounting Research, Vol. 43, No. 2 (May), pp. 153-93. 
, K. Raghunandan and K. R. Subramanyam (2002), 'Do Non-Audit Service Fees Impair Auditor Independence? Evidence from Going Concern Audit Opinions', Journal of Accounting Research, Vol. 40, No. 4, pp. 1247-74.

DeZoort, F.T. and S. Salterio (2001), 'The Effects of Corporate Governance Experience and Financial Reporting and Audit Knowledge on Audit Committee Members' Judgments,' Auditing: A Journal of Practice E Theory, Vol. 20, pp. 31-47.

- D.R. Hermanson, D.S. Archambeault and S.A. Reed (2002), 'Audit Committee Effectiveness: A Synthesis of the Empirical Audit Committee Literature', Journal of Accounting Literature, Vol. 21, pp. 38-75.

Doidge, C., G. A. Karolyi and M.S. Rene (2007), 'Why Do Countries Matter So Much for Corporate Governance?', Journal of Financial Economics, Vol. 86, No. 1, pp. 1-39.

Firth, M. (1997), 'The Provision of Non-Audit Services and the Pricing of Audit Fees', Journal of Business Finance $\mathcal{E}^{2}$ Accounting, Vol. 24, No. 3, pp. 511-25.

- (2002), 'Auditor Provided Consultancy Services and their Associations with Audit Fees and Audit Opinions', Journal of Business Finance $\mathcal{E}$ Accounting, Vol. 29, Nos. 5\&6, pp. 661-93.

Gaynor, L. M., L. S. McDaniel and T. L. Neal (2006), 'The Effects of Joint Provision and Disclosure of Non-Audit Services on Audit Committee Members' Decisions and Investors' Preferences,' The Accounting Review, Vol. 81, No. 4, pp. 873-96.

Goodwin-Stewart, J. and P. Kent (2006), 'Relation between External Audit Fees, Audit Committee Characteristics and Internal Audit', Accounting $\mathcal{E}$ Finance, Vol. 46, pp. 387-404.

Gregory, G. and P. Collier (1996), 'Audit Fees and Auditor Change: An Investigation of the Persistence of Fee Reduction by Type of Change', Journal of Business Finance Eे Accounting, Vol. 23, No. 1, pp. 3-28.

Hay, D., W.R. Knechel and V. Li (2006a), 'Non-Audit Services and Auditor Independence: New Zealand Evidence', Journal of Business Finance $\mathcal{E}$ Accounting, Vol. 33, Nos. 5\&6, pp. 715-34.

_ Demand Attributes', Contemporary Accounting Research, Vol. 23, No. 1, pp. 141-91. and H. Ling (2008), 'Evidence on the Impact of Internal Control and Corporate Governance on Audit Fees', International Journal of Auditing, Vol. 12, pp. 9-24.

Henry, D. (2008), 'Corporate Governance Structure and the Valuation of Australian Firms: Is There Value in Ticking the Boxes?,' Journal of Business Finance E् Accounting, Vol. 35, Nos. 7 \& 8, pp. 912-42.

Higgs Report (2003), Review of the Role and Effectiveness of Non-Executive Directors (www.dti.gov.uk/ cld/non_exec_review).

Hudaib, M. and T. Cooke (2005), 'The Impact of Managing Director Changes and Financial Distress on Audit Qualification and Auditor Switching', Journal of Business Finance $\mathcal{E}^{\circ}$ Accounting, Vol. 32, No. 9, pp. 1703-39.

Jensen, M. (1993), 'The Modern Industrial Revolution, Exit, and Failure of Internal Control Systems,' Journal of Finance, Vol. 48, pp. 831-80.

Kalbers, L.P. and T. Fogarty (1993), 'Audit Committee Effectiveness; An Empirical Investigation of the Contribution of Power', Auditing: A Journal of Practice and Theory, Vol. 12 (Spring), pp. 24-49.

Khanna, T., J. Kogan and K. Palepu (2006), 'Globalization and Similarities in Corporate Governance: A Cross-Country Analysis', Review of Economics and Statistics, Vol. 88, pp. 69-90.

Knapp, M. C. (1987), 'An Empirical Study of Audit Committee Support for Auditors Involved in Technical Disputes with Client Management', The Accounting Review, Vol. 62, No. 3, pp. 578.

Knechel, W.R. and M. Willekens (2006), 'The Role of Risk Management and Governance in Determining Audit Demand', Journal of Business Finance $\mathcal{E}$ Accounting, Vol. 33, Nos. 9-10, pp. 1344-67.

Krishnan, J. (2005), 'Audit Committee Quality and Internal Control: An Empirical Analysis', The Accounting Review, Vol. 80, No. 2, pp. 649-75.

and G. Visvanathan (2009), 'Do Auditors Price Audit Committee's Expertise? The Case of Accounting versus Non-Accounting Financial Experts', Journal of Accounting, Auditing $\mathcal{E}$ Finance, Vol. 24, No. 1, pp. 115-44.

Larcker, D. F. and S. A. Richardson (2004), 'Fees Paid to Audit Firms, Accrual Choices, and Corporate Governance,' Journal of Accounting Research, Vol. 42, No. 3, pp. 625-58.

McElveen, M. (2002), 'New Rules, New Challenges', Internal Auditor (December), pp.40-47. 
McMeeking, K. P., K. V. Peasnell and P. Pope (2006), 'The Determinants of the UK Big Firm Premium', Accounting E Business Research, Vol. 36, No. 3, pp. 207-31.

Menon, K. and J.D. Williams (1994), 'The Use of Audit Committees for Monitoring', Journal of Accounting and Public Policy, Vol. 13, pp. 121-39.

O'Sullivan, N. (1999), 'Board Characteristics and Audit Pricing Post-Cadbury: A Research Note', European Accounting Review, Vol. 8, pp. 253-63.

- (2000), 'The Impact of Board Composition and Ownership on Audit Quality: Evidence from Large UK Companies,' British Accounting Review, Vol. 32, pp. 397-414.

Parkash, M. and C.F. Venable (1993), 'Auditee Incentives for Auditor Independence: Case of Non-Audit Services', The Accounting Review, Vol. 68, No. 1 (January), pp. 113-33.

Peasnell, P., P. Pope and S. Young (2005), 'Board Monitoring and Earnings Management: Do Outside Directors Influence Abnormal Accruals?', Journal of Business Finance E Accounting, Vol. 32, No. 7, pp. 1311-46.

Peel, M.J. and M.A. Clatworthy (2001), 'The Relationship Between Governance Structure and Audit Fees Pre-Cadbury: Some Empirical Findings', Corporate Governance: An International Review, Vol. 9, No. 4, pp. 286-98.

Pincus, K., M. Rubarsky and J. Wong (1989), 'Voluntary Formation of Corporate Audit Committees Among NASDAQ Firms,' Journal of Accounting and Public Policy, Vol. 8, No. 4, pp. 239-65.

Pong, C. (1999). 'Auditor Concentration: A Replication and Extension for the UK Audit Market 1991 \& 1995', Journal of Business Finance E् Accounting, Vol. 26, Nos. 3 \& 4, pp. 451-75.

Raghunandan, K., W.J. Read and D.V. Rama (2001), 'Audit Committee Composition, "Gray Directors," and Interaction With Internal Auditing,' Accounting Horizons, Vol. 15, pp. 105-18.

Roberts, C, P. Weetman and P. Gordon (2005), International Financial Accounting: A Comparative Approach. (FT Pitman, 3rd ed.).

Sarbanes, P. and M. Oxley (2002), Sarbanes-Oxley Act of 2002, The Public Company Accounting Reform and Investor Protection Act (Washington DC: US Congress).

Sekaran, U. (1992), Research for Business: A Skill-Building Approach (John Wiley).

Sharma, D. S. and J. Sidhu (2001), 'Professionalism vs Commercialism: The Association Between Non-Audit Services (NAS) and Audit Independence', Journal of Business Finance E Accounting, Vol. 28, Nos. 5 \& 6, pp. 563-94.

Simunic, D.A. (1980), 'The Pricing of Audit Services: Theory and Evidence', Journal of Accounting Research, Vol. 18, No. 1 (Spring), pp. 161-89.

Smith Report (2003), Audit Committees Combined Code of Guidance (Financial Reporting Council, January, London).

Tsui, J., B. Jaggi and F. Gul (2001), 'CEO Determination, Growth Opportunities, and Their Impact on Audit Fees,' Journal of Accounting, Auditing, E Finance, Vol. 16, pp. 189- 208.

Turley, S. and M. Zaman (2004), 'The Corporate Governance Effects of Audit Committees', Journal of Management and Governance, Vol. 8, pp. 305-32.

$12007)$, 'Audit Committee Effectiveness: Informal Processes and Behavioural Effects', Accounting, Auditing $\mathcal{E}$ O Accountability Journal, Vol. 20, No. 5, pp. 765-88.

Waterlow Stock Exchange Yearbook (2005) (Waterlow Specialist Information Publishing).

Whisenant, S., S. Srinivasan and K. Raghunandan (2003), 'Evidence on the Joint Determination of Audit and Non-Audit Fees', Journal of Accounting Research, Vol. 41, No. 4, pp. 721-44.

Young, S. (2000), 'The Increasing Use of Non-Executive Directors: Its Impact on UK Board Structure and Governance Arrangements', Journal of Business Finance $\mathcal{E} \mathcal{F}^{\circ}$ Accounting, Vol. 27, Nos. 9 \& 10, pp. 1311-42.

Zhang, Y., J. Zhou and N. Zhou (2007), 'Audit Committee Quality, Auditor Independence and Internal Control Weaknesses', Journal of Accounting and Public Policy, Vol. 26, pp. 300-27. 